\title{
Focal Adhesion Kinase Signaling Mediates Acute Renal Injury Induced by Ischemia/Reperfusion
}

\author{
Yu Qin, ${ }^{*}$ Maaike C. Alderliesten, ${ }^{*}$ Geurt Stokman, ${ }^{*}$ \\ Petra Pennekamp, ${ }^{\dagger}$ Joseph V. Bonventre, ${ }^{\neq}$ \\ Emile de Heer, ${ }^{\S}$ Takaharu Ichimura, ${ }^{\ddagger}$ \\ Marjo de Graauw, ${ }^{*}$ Leo S. Price, ${ }^{*}$ and \\ Bob van de Water* \\ From the Division of Toxicology, ${ }^{*}$ Leiden/Amsterdam Center for \\ Drug Research, Leiden University, Leiden, The Netherlands; the \\ Institute of Human Genetics, ${ }^{\dagger}$ University Hospital Münster, \\ Münster, Germany; the Renal Division, ${ }^{\ddagger}$ Department of Medicine, \\ Brigham and Women's Hospital, Harvard Medical School, \\ Boston, Massachusetts; and the Department of Pathology, ${ }^{\S}$ Leiden \\ University Medical Center, Leiden, The Netherlands
}

Renal ischemia/reperfusion (I/R) injury is associated with cell matrix and focal adhesion remodeling. Focal adhesion kinase (FAK) is a nonreceptor protein tyrosine kinase that localizes at focal adhesions and regulates their turnover. Here, we investigated the role of FAK in renal $I / R$ injury, using a novel conditional proximal tubule-specific $f a k$-deletion mouse model. Tamoxifen treatment of FAK $^{\text {loxP/loxP } / / \gamma G T-}$ Cre-ER ${ }^{\mathrm{T} 2}$ mice caused renal-specific fak recombination $\left(F K^{\Delta l o x P / \Delta l o x P}\right)$ and reduction of FAK expression in proximal tubules. In $\mathrm{FAK}^{\Delta \operatorname{loxP} / \Delta \operatorname{loxP}}$ mice compared with FAK ${ }^{\text {loxP/loxP }}$ controls, unilateral renal ischemia followed by reperfusion resulted in less tubular damage with reduced tubular cell proliferation and lower expression of kidney injury molecule-1, which was independent from the postischemic inflammatory response. Oxidative stress is involved in the pathophysiology of $\mathbf{I} / \mathbf{R}$ injury. Primary cultured mouse renal cells were used to study the role of FAK deficiency for oxidative stress in vitro. The conditional fak deletion did not affect cell survival after hydrogen peroxide-induced cellular stress, whereas it impaired the recovery of focal adhesions that were disrupted by hydrogen peroxide. This was associated with reduced $c$-Jun $\mathbf{N}$-terminal kinase-dependent phosphorylation of paxillin at serine 178 in FAK-deficient cells, which is required for focal adhesion turnover. Our findings support a role for FAK as a novel factor in the initiation of c-Jun $\mathbf{N}$-terminal kinase-mediated cellular stress response during renal
$\mathbf{I} / \mathbf{R}$ injury and suggest FAK as a target in renal injury protection. (Am J Pathol 2011, 179:2766-2778; DOI: 10.1016/j.ajpath.2011.08.025)

Renal ischemia/reperfusion (I/R) injury is a potential lifethreatening clinical problem and may occur during hypoperfusion of the kidney or after renal transplantation. ${ }^{1}$ During renal I/R injury, proximal tubular epithelial cells may detach from the extracellular matrix, leading to intraluminal obstruction or cell excretion in the urine. ${ }^{2}$ Considerable attention has been directed to the role of cellextracellular matrix adhesion-mediated signaling during I/R injury. ${ }^{3-5}$ Understanding the basic molecular mechanisms that underlie disruption of cell adhesion during the course of $I / R$ injury is essential for the development of therapeutic strategies that antagonize cell detachment and subsequent cell stress signaling to prevent acute renal failure or to promote tissue regeneration.

Adhesion of cells to the extracellular matrix is essential for the control of cell survival, proliferation, differentiation, and migration. ${ }^{6}$ Cell-extracellular matrix adhesions are mediated via engagement of integrins with their extracellular ligands and subsequent assembly of an intracellular multiprotein complex termed focal adhesion (FA) complex. ${ }^{6,7}$ FAs are prominently present at the basolateral membrane of proximal tubular epithelial cells in vivo ${ }^{5}$ and allow activation of divergent downstream signaling cascades that modulate various adhesion-dependent biological processes. I/R injury induces alterations in the F-actin cytoskeleton ${ }^{8}$ and redistribution of integrins ${ }^{3}$ and

Supported by The Netherlands Organisation for Scientific Research grant NWO 908-02-107 (M.C.A.), The Netherlands Toxicogenomics Center (L.S.P.), The Dutch Kidney Foundation (G.S.), and a scholarship from the China Scholarship Council (Y.Q.).

Accepted for publication August 24, 2011

Y.Q. and M.C.A. contributed equally to this manuscript.

Supplemental material for this article can be found at http://ajp. amjpathol.org or at doi: 10.1016/j.ajpath.2011.08.025.

Current address of M.C.A., The Netherlands Cancer Institute, Amsterdam, The Netherlands.

Address reprint requests to Bob van de Water, Ph.D., Division of Toxicology, LACDR, Leiden University, Einsteinweg 55, PO Box 9502, 2300 RA Leiden, The Netherlands. E-mail: b.water@lacdr.leidenuniv.nl. 
other FA-associated signaling proteins. ${ }^{5}$ Disruption of adhesion was associated with dephosphorylation of FA proteins during hypoxia in isolated tubules ${ }^{9}$ and $\mathrm{I} / \mathrm{R}$ injury in vivo. ${ }^{5}$ The effect of disruption of FA-mediated signaling events on the pathogenesis of acute renal failure is however still unclear.

Focal adhesion kinase (FAK) is a nonreceptor protein tyrosine kinase that localizes at FAs and regulates FA dynamics. ${ }^{10}$ Integrin-mediated adhesion induces autophosphorylation of tyrosine residue 397 on FAK, providing a docking site for various adapter signaling proteins such as c-Src, p130Cas, and phospho-inositide-3 kinase. ${ }^{11}$ Through these interactions, FAK is implicated in the regulation of signaling pathways that control cell adhesion dynamics, ${ }^{10}$ cell survival, ${ }^{12}$ proliferation, ${ }^{13}$ and inflammatory responses. ${ }^{14}$ We have reported that in renal I/R injury FAs undergo drastic restructuring, associated with rapid dephosphorylation of FAK directly after the ischemic period followed by enhanced rephosphorylation of FAK during the reperfusion. ${ }^{5}$ We propose that FAK plays an important role in the pathophysiology of I/Rmediated renal failure.

Here, we investigated the role of FAK in I/R-induced renal injury in vivo. Because fak knockout mice are embryonically lethal, ${ }^{15}$ we created a Cre/LoxP systembased conditional proximal tubule-specific fak knockout mouse model by crossing floxed fak (FAK $\left.{ }^{\text {loxP/loxP }}\right)$ mice $^{16}$ with $\gamma$ GT-Cre-ER ${ }^{\mathrm{T} 2}$ mice. ${ }^{17}$ Our data show that in vivo proximal tubular FAK deficiency attenuates I/R-induced renal injury. To study the role of FAK deficiency in vitro, we used FAK-deficient primary cultured renal cells and used an exposure model to hydrogen peroxide $\left(\mathrm{H}_{2} \mathrm{O}_{2}\right)$ that mimics reperfusion-associated oxidative stress. $\mathrm{H}_{2} \mathrm{O}_{2}$-induced turnover of FA and activation of cell stress pathways were compared between FAK-expressing and FAKdeficient cells. The in vitro data suggest that FAK mediates FA turnover and thus weakens the stability of FAs during reperfusion after renal ischemia. FAK is also involved in the initiation of the C-Jun N-terminal kinase (JNK)-mediated cellular stress response to I/R injury, accompanied by early tubular epithelial injury responses that occur during the pathophysiological process associated with acute renal failure.

\section{Materials and Methods}

\section{Materials}

Dulbecco's modified Eagle's medium/Ham's F12 (1:1), phosphate-buffered saline (PBS), and penicillin/streptomycin/amphotericin B were from Invitrogen (Carlsbad, CA). Fetal bovine serum was from Life Technologies (Grand Island, NY). Collagenase (Crude, type XI), epidermal growth factor, $1 \times$ insulin-transferrin sodium selenite supplement, cholera toxin, $\mathrm{H}_{2} \mathrm{O}_{2}$, and all of the other reagents not specially referred to were obtained from Sigma-Aldrich (St. Louis, MO).

\section{Mice, Genotyping, and Recombination PCR}

FAK ${ }^{\text {loxP/loxP }}, 16$ GT-Cre-ER ${ }^{\text {T2 }}, 17$ and Rosa-Cre-ER ${ }^{\text {T2 } 18}$ mice were maintained and bred at the animal facility of the Leiden University Gorlaeus Laboratories in accordance with institutional guidance and national health standards. The mice were regularly monitored and had free access to water and standard mice chow.

Mice were genotyped with PCR. Genomic DNA was isolated from ear cuts, and FAK ${ }^{\text {loxP/loxP }}$ and $F A K^{w t / w t}$ bands (400 bp and $290 \mathrm{bp}$, respectively) were detected with $5^{\prime}$-GAGAATCCAGCTTTGGCTGTTG-3' and 5' GAATGCTACAGGAACCAAATAAC-3' primers and the following conditions: 5 minutes at $95^{\circ} \mathrm{C}$ (one cycle); 30 seconds at $94^{\circ} \mathrm{C}, 30$ seconds at $62^{\circ} \mathrm{C}$, and 1 minute at $72^{\circ} \mathrm{C}$ (35 cycles); and 5 minutes at $72^{\circ} \mathrm{C}$. Cre-ER ${ }^{\mathrm{T} 2}$ bands were detected with 5'-GTTCAGGGATCGCCAGGCG-3' and 5'-GCTGGCTGGTGGCAGATGG-3' primers and the following conditions: 5 minutes at $95^{\circ} \mathrm{C}$ (one cycle); 1 minute at $94^{\circ} \mathrm{C}, 1$ minute at $65^{\circ} \mathrm{C}$, and 2 minutes at $72^{\circ} \mathrm{C}$ (30 cycles); and 10 minutes at $72^{\circ} \mathrm{C}$. PCR products were separated on $2 \%$ agarose gels.

For each mouse used in the experiment, three cryosections $(10 \mu \mathrm{m})$ of the right, unaffected kidney were lysed for DNA extraction. DNA extracted from mouse kidney or cultured primary mouse renal cells were detected for the presence of fak recombination with the use of 5'-GACCTTCCAACTTCTCATTTCTCC-3' and 5'GAATGCTACAGGAACCAAATAAC-3' primers and the following conditions: 5 minutes at $95^{\circ} \mathrm{C}$ (one cycle); 30 seconds at $94^{\circ} \mathrm{C}, 30$ seconds at $62^{\circ} \mathrm{C}$, and 1 minute at $72^{\circ} \mathrm{C}$ (35 cycles); and 5 minutes at $72^{\circ} \mathrm{C}$. PCR products were separated on $2 \%$ agarose gels.

\section{Tamoxifen Treatment of Mice}

Tamoxifen powder (300 mg; Sigma-Aldrich) was dissolved in $900 \mu \mathrm{L}$ of absolute ethanol and suspended in $5.1 \mathrm{~mL}$ of sunflower oil. This suspension $(50 \mathrm{mg} / \mathrm{mL})$ was sonicated twice for 30 seconds to generate a clear solution and stored in aliquots at $-20^{\circ} \mathrm{C}$. The solution was thawed at $37^{\circ} \mathrm{C}$ and administered orally to mice (100 $\mu \mathrm{L}$ ) by a feeding needle for 4 consecutive days followed by a period of 4 days without treatment, before analysis and the onset of the $\mathrm{I} / \mathrm{R}$ injury.

\section{Renal I/R Injury}

Male mice (12 to 14 weeks of age) were anesthetized with $3 \%$ isoflurane in a mix of $60 \% \mathrm{~N}_{2} \mathrm{O}$ and $40 \% \mathrm{O}_{2}$. A small incision was made over the left flank; the left renal pedicle was prepared and clamped with a B1 hemostatic clamp (Fine Science Tools, Heidelberg, Germany) for 35 minutes, whereas the right kidney was unaffected and served as internal control. After removal of the clamp, the incision was closed with nondegradable sutures. Animals were sacrificed at 24 hours after ischemia. Both kidneys were harvested and prepared as described below. Additional control kidneys were obtained from animals that underwent sham surgery without I/R injury. Each group consisted of a minimum of eight animals. All of the kid- 
neys were briefly washed in ice-cold PBS to remove excess blood and sliced into two equal halves. One half of each kidney was frozen in liquid nitrogen and stored at $-80^{\circ} \mathrm{C}$. The other half was fixed in ice-cold Carnoy's solution $[60 \%(\mathrm{v} / \mathrm{v})$ absolute ethanol, $30 \%(\mathrm{v} / \mathrm{v})$ chloroform, and 10\% (v/v) glacial acetic acid] for 3 hours and thereafter transferred to $70 \%(\mathrm{v} / \mathrm{v})$ ethanol and stored at $4^{\circ} \mathrm{C}$. All experiments that used mice were approved by the local animal experimental committee of the Leiden University.

\section{Isolation and Culture of Primary Mouse Renal Cells}

For in vitro experiments, mouse renal cells were isolated from the kidneys of male FAK ${ }^{\text {loxP/loxP//Rosa-Cre-ER }}{ }^{\mathrm{T} 2}$ mice $(\sim 25 \mathrm{~g})$ or the FAK ${ }^{\text {loxP/loxP }}$ littermates. The kidneys were minced and digested in a collagenase solution in Hanks' HEPES balanced salt solution (137 mmol/L NaCl, 5 $\mathrm{mmol} / \mathrm{L} \mathrm{KCl}, 0.8 \mathrm{mmol} / \mathrm{L} \mathrm{MgSO}_{4}, 0.4 \mathrm{mmol} / \mathrm{L} \mathrm{Na}{ }_{2} \mathrm{HPO}_{4}, 0.4$ $\mathrm{mmol} / \mathrm{L} \mathrm{KH}_{2} \mathrm{PO}_{4}, 1.3 \mathrm{mmol} / \mathrm{L} \mathrm{CaCl}, 4 \mathrm{mmol} / \mathrm{L} \mathrm{NaHCO}_{3}$, $25 \mathrm{mmol} / \mathrm{L}$ HEPES, $5 \mathrm{mmol} / \mathrm{L}$ D-glucose, $\mathrm{pH}$ 7.4) for 30 minutes at $37^{\circ} \mathrm{C}$. The cell suspension was washed three times in Hanks' HEPES balanced salt solution. After washing, cells were resuspended in Dulbecco's modified Eagle's medium/Ham's F12 (1:1) containing 1\% (v/v) fetal bovine serum, $0.5 \mathrm{mg} / \mathrm{mL}$ bovine serum albumin, 10 $\mathrm{ng} / \mathrm{mL}$ epidermal growth factor, $10 \mathrm{ng} / \mathrm{mL}$ cholera toxin, $50 \mathrm{nmol} / \mathrm{L}$ hydrocortisone, $15 \mathrm{mmol} / \mathrm{L}$ HEPES, $2 \mathrm{mmol} / \mathrm{L}$ glutamine, $1 \times$ insulin-transferrin sodium selenite supplement, and $1 \%(\mathrm{v} / \mathrm{v})$ penicillin/streptomycin/amphotericin $\mathrm{B}$ and were maintained at $37^{\circ} \mathrm{C}$ in a humidified atmosphere of $95 \%$ air $/ 5 \% \mathrm{CO}_{2}$. To induce fak recombination, cells were exposed to 4-hydroxy-tamoxifen (4-OHT; Sigma-Aldrich), and medium was refreshed every other day. After 7 to 9 days of culturing, confluent monolayer was subjected to $1 \mathrm{mmol} / \mathrm{L} \mathrm{H}_{2} \mathrm{O}_{2}$ in serum-free medium for indicated time periods.

\section{Histopathology and Immunohistochemistry}

Fixed kidneys were embedded in paraffin in a standard fashion and sectioned (3 $\mu \mathrm{m})$. Sections were deparaffinized, stained with $\mathrm{H} \& \mathrm{E}$, and examined for tubular injury. Tubulo-interstitial injury was assessed in the cortex, outer stripe of the outer medulla (OSOM), and inner stripe of the outer medulla (ISOM) with the use of a semiquantitative scoring index as previously described. ${ }^{5}$ In short, tubular cast formation, tubular dilatation, and tubular degeneration (vacuolar change, loss of brush border, detachment of tubular epithelial cells, and condensation of tubular nuclei) were scored blind by two independent observers according to the following criteria: 0 , normal; $1,<30 \% ; 2,30 \%$ to $70 \%$; and $3,>70 \%$ of the pertinent area. After scoring all individual scores per kidney were added together to define the overall tubular damage in the kidney.

For immunohistochemistry of kidney injury molecule-1 (KIM-1), paraffin sections of the kidneys were stained as described previously. ${ }^{19}$ Briefly, after antigen retrieval, sections were blocked with normal goat serum (NGS;
Vector Laboratories, Burlingame, CA) and incubated with primary antibody for 1 hour. Sections were labeled with biotinylated goat anti-mouse/rabbit IgG, and staining was visualized with an avidin-biotinylated horseradish peroxidase complex. Nuclei were counterstained with toluidine blue. For KIM-1 staining the sections were scored blind by two independent observers according to the following criteria: 0 , no staining; 0.5 , one tubule; 1 , very few tubules; 2, several tubules but not widespread; 3, widespread staining or entire OSOM; and 4, many tubules stained beyond OSOM.

For immunohistochemistry of CD45 and F4/80, cyrosections $(10 \mu \mathrm{m})$ were air dried and fixed in acetone for 10 minutes. After blocking with NGS, sections were incubated with rat anti-mouse CD45 (Abcam, Oxford, UK) for 1 hour and rat anti-mouse F4/80 (Abcam) overnight. Sections were then labeled with horseradish peroxidase-conjugated rabbit anti-rat IgG and counterstained with hematoxylin.

All of the stainings were examined with light microscopy (Leica DM6000B, Wetzlar, Germany).

\section{Immunofluorescence}

Cryosections were immunostained for FAK as described previously. ${ }^{5}$ Briefly, sections were fixed in ice-cold $4 \%$ buffered formaldehyde for 10 minutes and blocked in 5\% $(\mathrm{v} / \mathrm{v})$ NGS for 1 hour. The sections were then incubated overnight at $4^{\circ} \mathrm{C}$ in a humidified chamber with rabbit polyclonal anti-FAK antibody (Millipore, Billerica, MA) and subsequently incubated with Alexa 488-labeled goat anti-rabbit lgG (Invitrogen). Rhodamine-conjugated phalloidin (Molecular Probes, Eugene, OR) was used for Factin staining. Sections were counterstained with Hoechst 33258 dye and mounted with Aqua-Poly/Mount (Polysciences, Warrington, PA).

For cleaved caspase-3 and Ki-67 stainings, 10- $\mu \mathrm{m}$ cryosections were air dried and fixed in $4 \%$ buffered formaldehyde. Sections were permeabilized in $0.2 \%$ Triton $\mathrm{X}-100$ in PBS and blocked with 5\% NGS in PBS with $0.05 \%$ Triton $X-100$. Then the sections were incubated overnight with rabbit polyclonal anti-cleaved caspase-3 (Asp175) antibody (Cell Signaling Technologies, Danvers, MA) or rabbit polyclonal anti-Ki-67 antibody (Novocastra, Newcastle, UK). Sections were subsequently incubated with cyanine-3-labeled goat anti-rabbit IgG (Invitrogen) and counterstained with Hoechst 33258 dye. All antibodies were diluted in PBS with $0.05 \%$ Triton $\mathrm{X}$-100. Cleaved caspase-3-positive or Ki-67-positive cells were counted blind in the cortex, OSOM, and ISOM with the use of $40 \times$ objective by two independent observers and expressed as the number of positive cells per highpower field.

Fixed cells on coverslips were permeabilized with 0.4\% (w/v) Triton X-100 in PBS for 10 minutes, followed by three washes with PBS. After blocking with $5 \%(\mathrm{v} / \mathrm{v})$ NGS and $1 \%(\mathrm{w} / \mathrm{v})$ bovine serum albumin in PBS, cells were stained for anti-vinculin (Transduction Laboratories, Lex-

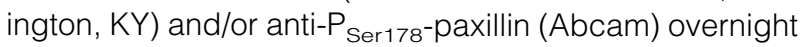
at $4^{\circ} \mathrm{C}$. Thereafter, cells were washed three times with PBS and subsequently incubated with cyanine-3-labeled goat anti-mouse IgG and/or Alexa 488-labeled goat anti- 
rabbit IgG (Invitrogen), in combination with Hoechst 33258. Coverslips were mounted on glass slides with the use of Aqua-Poly/Mount.

Images were made with a Nikon E600 epifluorescence microscope (Nikon, Tokyo, Japan) or Bio-Rad Radiance 2100 confocal system with a $\times 60$ Plan Apo objective (NA 1.4; Nikon, Melville, NY). All images were processed with Image-Pro Plus version 5.1 (Media Cybernetics, Bethesda, MD).

\section{Western Blot Analysis}

Western blot samples were processed as described previously. ${ }^{5}$ Briefly, cryosections were lysed in Triton lysis buffer $(20 \mathrm{mmol} / \mathrm{L}$ Tris, $\mathrm{pH} 7.4,137 \mathrm{mmol} / \mathrm{L} \mathrm{NaCl}, 2$ mmol/L EDTA, $1 \%$ Triton X-100, 25 mmol/L $\beta$-glycerophosphate, and $10 \%$ glycerol) with protease inhibitors. Lysates were syringed four times though a 26-guage needle, centrifuged, and immediately boiled in sample preparation buffer $(125 \mathrm{mmol} / \mathrm{L}$ Tris- $\mathrm{HCl}, \mathrm{pH} 6.8,20 \%$ glycerol, $4 \%$ SDS, and bromophenol blue) plus $\beta$-mercaptoethanol. Equal amounts of protein samples were separated by SDS-PAGE and transferred to nitrocellulose membrane (Whatman, Dassel, Germany). Blots were blocked either in $5 \%(\mathrm{w} / \mathrm{v})$ bovine serum albumin in Tris-buffered saline/Tween 20 [0.5 mol/L NaCl, 20 $\mathrm{mmol} / \mathrm{L}$ Tris- $\mathrm{HCl}$, and $0.05 \%(\mathrm{v} / \mathrm{v})$ Tween 20, pH 7.4], or l-block $[0.2 \%(\mathrm{w} / \mathrm{v})$ casein in Tris-buffered saline/ Tween 20] for 1 hour at room temperature. Primary antibody incubation was performed overnight at $4^{\circ} \mathrm{C}$

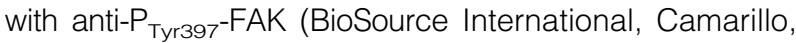
CA); anti-FAK (clone77; Millipore); anti-P Ser178-paxillin (Abcam); anti- $P_{\text {Tyr 118 }}$-paxillin (BioSource International); anti-paxillin (Transduction Laboratories); anti- $P_{\text {Thr183 }}$ $\mathrm{P}_{\text {Tyr185-JNK; anti-JNK; anti-P }}$ Ser63 $^{-C}$-Jun (Cell Signaling Technologies); anti-c-Jun (Oncogene Science, Uniondale, NY) and anti-tubulin (Sigma-Aldrich). Thereafter, blots were incubated with either horseradish peroxidaseconjugated secondary antibody (Jackson ImmunoResearch Laboratories, West Grove, PA) in Tris-buffered saline/Tween 20 , or alkaline phosphatase-conjugated secondary antibody (Applied Biosystems, Foster City, $\mathrm{CA}$ ) in I-block for 1 hour at room temperature. Protein signals were detected with the ECL Plus reagent (GE Healthcare, Little Chalfont, Buckinghamshire, UK) by imaging with the Typhoon 9400 (GE Healthcare), or with Tropix Western-Star Kit by films. Densitometric analysis of the protein band intensity was performed with ImageJ v1.410 analysis software (http://imagej.nih.gov/ij).

\section{ELISA for MCP-1 and IL-6}

Medium samples from cell culture were collected for the measurement of secreted IL-6 and monocyte chemoattractant protein 1 (MCP-1) with the use of mouse IL-6 and MCP-1 enzyme-linked immunosorbent assay kits according to the manufacturer's instructions (eBioscience, San Diego, CA).

\section{LDH Release Assay}

Total cell death was measured by the release of lactate dehydrogenase ( $L D H)$ from cells in the culture medium as a measure of plasma membrane permeability, as previously described. ${ }^{20}$ The percentage of free LDH leakage was calculated from the amount of LDH release caused by treatment relative to the amount of that released by $0.1 \%(w / v)$ Triton X-100 (ie, 100\% release).

\section{Statistics}

Data are expressed as mean \pm SEM. Statistical significance was determined with the Student's $t$-test, except for the semiquantitative scoring of H\&E and KIM-1 stainings in which the Mann-Whitney U-test was applied for nonparametric data. Significant difference was set when the $P$ value was $<0.05$. All statistical analyses were performed with Graphpad Prism 4 (GraphPad Software, San Diego, CA).

\section{Results}

\section{Conditional Renal Proximal Tubule-Specific Fak Knockout}

The role of FAK during I/R-induced injury was studied in a conditional proximal tubule-specific fak knockout mouse model that used the Cre/LoxP technology. Mice with LoxP sites flanking the second exon of the fak gene $\left(F A K^{\text {loxP/loxP }}\right)^{16}$ were crossed with transgenic mice that express Cre recombinase under control of the $\gamma \mathrm{GT}$ pro-

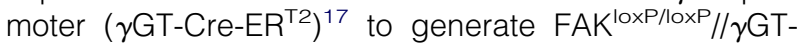
Cre-ER ${ }^{\mathrm{T} 2}$ offspring (Figure 1A).

We confirmed recombination of the fak alleles in primary cultured renal cells isolated from FAK loxP/loxP // $\gamma$ GT-Cre-ER ${ }^{\text {T2 }}$ and control FAK IoxP/loxP//Rosa-Cre-ER ${ }^{\text {T2 }}$ mice. Cre recombinase in FAK ${ }^{\text {loxP/loxp } / / R o s a-C r e-E R ~}{ }^{T 2}$ mice is ubiquitously expressed under the Rosa promoter, and the addition of the active metabolite 4-OHT induced complete recombination of the fak alleles coinciding with complete loss of FAK protein (Figure 1B). However, treatment of FAK ${ }^{\text {IoxP/loxP } / / \gamma G T-C r e-E R^{T 2}}$ renal cells with 4-OHT showed only partial recombination of the fak alleles. Cre expression driven by the $\gamma$ GT promoter predominantly occurs in the proximal tubular cells of the S3 segment, ${ }^{17}$ which represent a small fraction of the primary renal cell culture. Consequently, no significant decrease in FAK protein level was observed from 4-OHT-treated FAK ${ }^{\text {loxP/loxP } / / \gamma G T-C r e-E R^{T 2}}$ renal cells (Figure 1B).

To show fak recombination in animals, male FAK ${ }^{\operatorname{lox} P \text { IloxP } / /}$ $\gamma$ GT-Cre-ER ${ }^{\text {T2 }}$ mice and their FAK ${ }^{\text {loxP/loxP }}$ littermates were treated with $5 \mathrm{mg}$ of tamoxifen for 4 consecutive days to induce Cre recombinase activity. FAK loxP/loxP// Rosa-Cre-ER ${ }^{\mathrm{T} 2}$ mice served as controls. Four days after the last treatment, kidney, liver, and spleen were harvested, and fak recombination was shown by PCR analysis. All examined tissues from FAK ${ }^{\text {loxP/loxP//Rosa- }}$ Cre-ER ${ }^{\mathrm{T} 2}$ mice showed almost complete recombination 
A
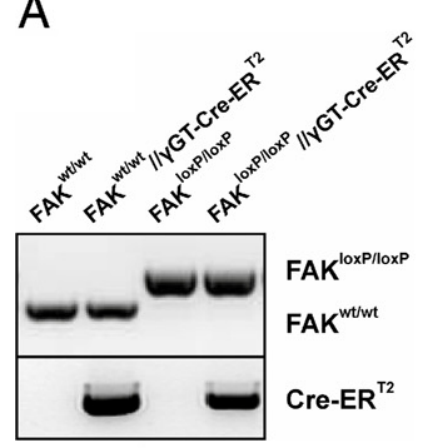

B

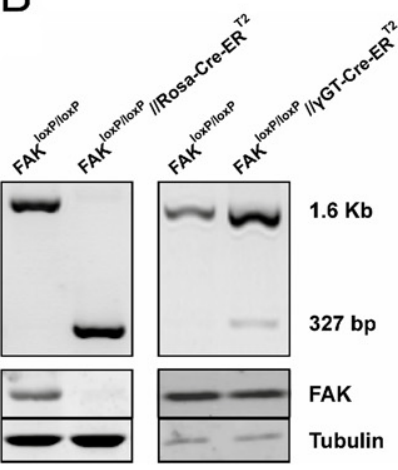

C

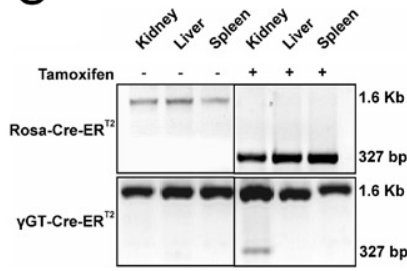

D

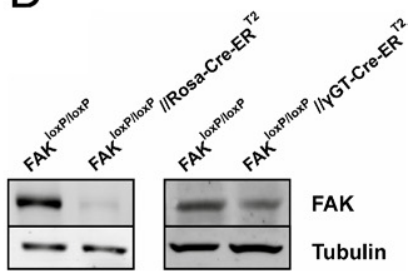

E FAK

F-actin

Merge
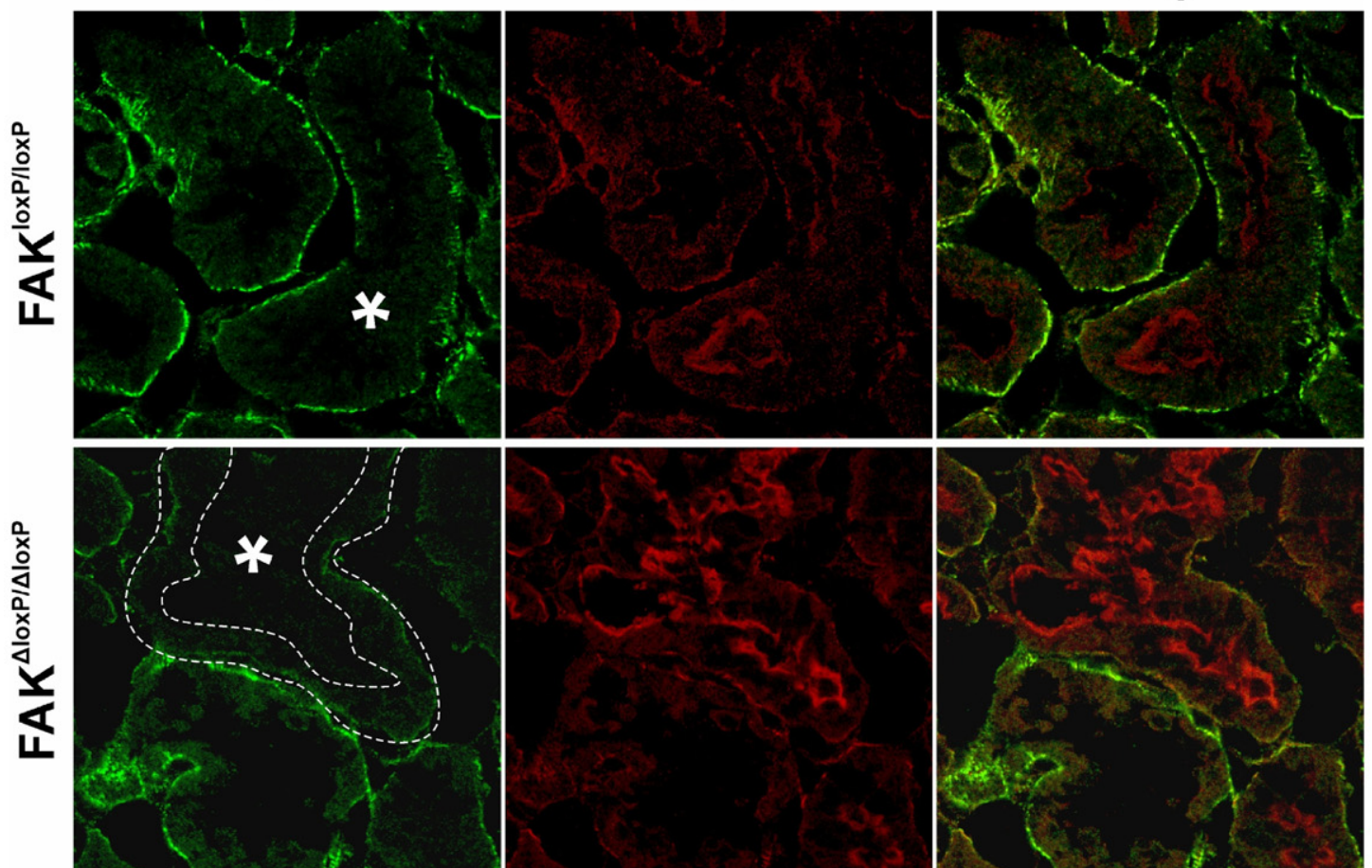

Figure 1. Tamoxifen successfully recombines "loxed" fak alleles in the mouse kidney. A: Representative PCR genotype analysis showing the successful breeding for the offspring derived from FAK ${ }^{\text {loxP/loxP }}$ and $\gamma G_{T}$ T-Cre-ER ${ }^{\mathrm{T} 2}$ strain crossbreeding (FAK ${ }^{\text {loxP } / \text { loxP }} / / \gamma G_{T}$-Cre-ER ${ }^{\mathrm{T} 2}$ ). B: Primary cultured renal cells from FAK ${ }^{\text {loxP/loxP }}$,

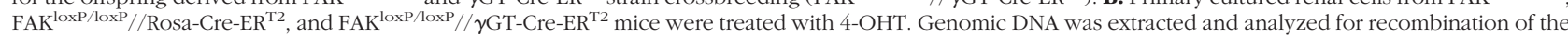
loxed fak alleles by PCR (upper panels). The recombination band appears at $327 \mathrm{bp}$. Protein level of FAK was detected by Western blot analysis (lower panels). Data show complete fak gene recombination and significant reduction of FAK protein in cells from FAK ${ }^{\text {loxP/loxP } / / R^{2}}$ osa-Cre-ER ${ }^{\mathrm{T} 2}$ animals, in contrast to the cells from $\mathrm{FAK}^{\mathrm{loxP} / \mathrm{loxP}} / / \gamma \mathrm{GT}$-Cre-ER ${ }^{\mathrm{T} 2}$ animals that only show partial recombination of fak gene, and no reduction of FAK protein was observed. C: Tissue specificity of $f a k$ recombination in $\mathrm{FAK}^{\mathrm{loxP} / \mathrm{loxP}} / /$ Rosa-Cre-ER ${ }^{\mathrm{T} 2}$ and $\mathrm{FAK} \mathrm{L}^{\mathrm{loxP} / \mathrm{loxP}} / / \gamma \mathrm{GT}$-Cre-ER ${ }^{\mathrm{T} 2}$ mice was examined in kidney, liver, and spleen tissue. Animals were treated with either $5 \mathrm{mg}$ of tamoxifen or vehicle daily for 4 days, and tissue samples were obtained 4 days after the last treatment. PCR results show that, in FAK $^{\text {loxP/loxP}} / / \gamma$ GT-Cre-ER ${ }^{\mathrm{T} 2}$ animals, tamoxifen-induced fak recombination only occurs in the kidney. Similar to the case in cultured cells, the recombination is not complete. D: Cryosections of kidneys from tamoxifen-treated FAK ${ }^{\text {loxP/loxP }}$, FAK ${ }^{\text {loxP } / \text { loxP }} / /$ Rosa-Cre-ER $^{\text {T2 }}$, and FAK ${ }^{\text {loxP/loxP }} / / \gamma \gamma$ T-Cre-ER ${ }^{\text {T2 }}$ mice were prepared for Western blot analysis to determine the protein level of FAK in kidney tissue. The results confirmed the observation from PCR that there is no obvious reduction of FAK in FAK ${ }^{\text {loxP/loxP }} / / \gamma G T-C r e-E^{T 2}$ animals. E: To determine the location of the FAK-deficient tubules in the kidney, cryosections of kidneys from tamoxifen-treated FAK ${ }^{\text {loxP/loxP}} / / \gamma G_{T}$-Cre-ER ${ }^{\mathrm{T} 2}$ mice and FAK ${ }^{\text {loxP/loxP }}$ littermates (FAK ${ }^{\Delta l o x P} / \Delta$ loxP and FAK ${ }^{\text {loxP/loxP }}$ animals, respectively) were stained for FAK (green) and F-actin (red). Tubular FAK expression at the basolateral cell membrane was unchanged in FAK ${ }^{\text {loxP/loxP }}$ animals, whereas the loss of FAK expression was observed in FAK ${ }^{\Delta \operatorname{loxP} / \Delta \operatorname{loxP}}$ animals (proximal tubule outlined and indicated by asterisk). All sections were imaged with confocal laser scanning microscopy. Sections are representative of proximal tubules from three different mice. Original magnification: $\times 60$.

of the fak alleles as detected by the presence of a 327-bp recombination band after tamoxifen treatment (Figure 1C). In tamoxifen-treated FAK ${ }^{\text {loxP/loxP } / / \gamma G T-C r e-E R^{T 2}}$ mice, the recombination band was weak, indicating partial recombination and consistent with our in vitro findings. More importantly, recombination was only observed in the kidney but not in liver or spleen tissue, showing the tissue specificity of fak recombination. Control FAK ${ }^{\text {loxP/loxP }}$ mice showed no recombination in any of the tissues (data not shown). Reduced FAK expression was observed in the kidney from tamoxifen-treated $\mathrm{FAK}^{\text {loxP/loxP} / / R o s a-C r e-E R ~}{ }^{\mathrm{T} 2}$ mice but was less evident in $\mathrm{FAK}^{\text {loxP/loxP} / / \gamma G T-C r e-E R^{T 2}}$ mice (Figure 1D). FAK-specific immunofluorescence staining of kidney tissue showed a lower FAK expression at basolateral membrane of proximal tubules after fak recombination in $\mathrm{FAK}^{\mathrm{loxP} / \text { loxP }} / / \gamma \mathrm{GT}-\mathrm{Cre}-\mathrm{ER}^{\mathrm{T2}}$ mice $\left(\mathrm{FAK}^{\Delta \mathrm{loxP} / \Delta \mathrm{loxP}}\right.$ mice) 
compared with $\mathrm{FAK}^{\text {loxP/loxP }}$ littermates (Figure 1E). Although the ubiquitous loss of renal FAK expression was observed in $\mathrm{FAK}^{\text {loxP/loxP} / / R o s a-C r e-E R ~}{ }^{\mathrm{T} 2}$ mice, the loss of FAK protein in FAK ${ }^{\text {loxP/loxP } / / \gamma G T-C r e-E R^{T 2}}$ mice was mostly observed in proximal tubules that locate in the
OSOM but not observed in distal tubules in either OSOM or cortex (see Supplemental Figure S1 at $h t t p: / /$ ajp.amjpathol.org). These data show that inducible renal proximal tubule-specific deletion of fak was achieved in $\mathrm{FAK}^{\text {loxP/loxP}} / / \gamma \mathrm{GT}$-Cre-ER ${ }^{\mathrm{T} 2}$ mice.
A
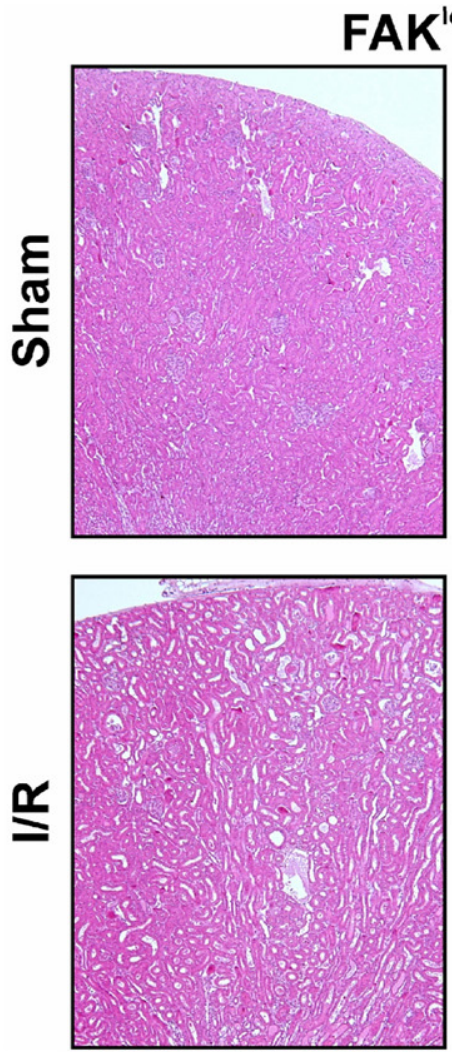

loxP/loxP
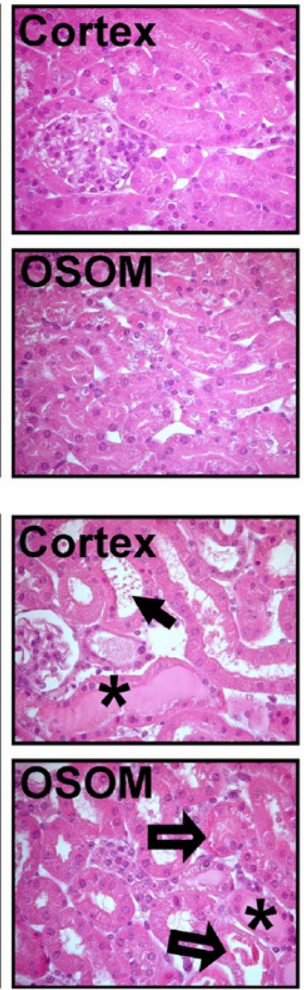

FAK $^{\Delta \text { loxP/AloxP }}$
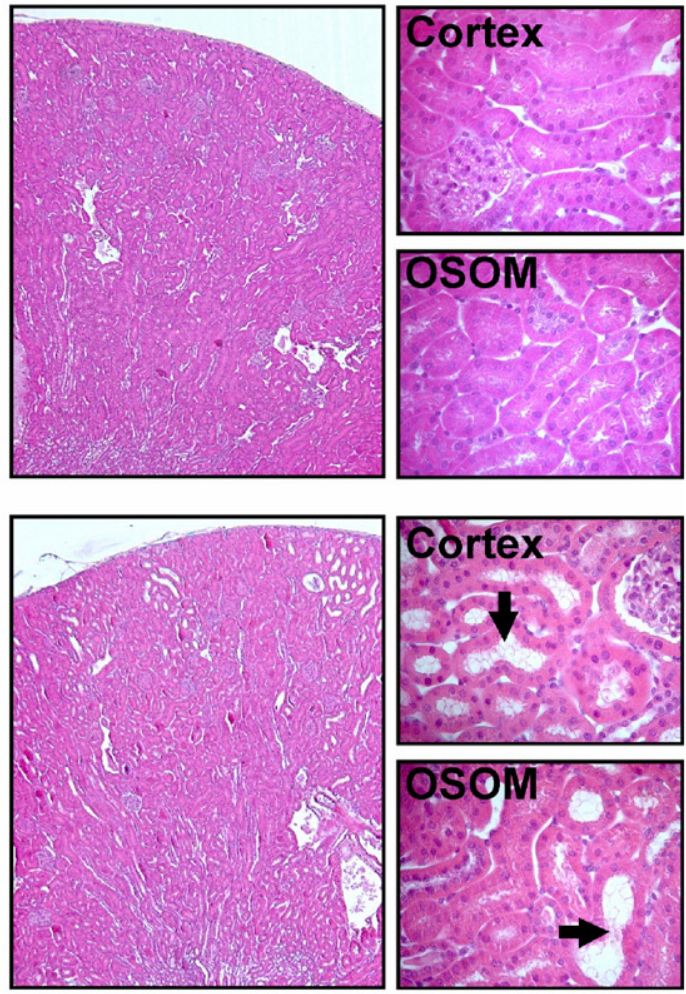
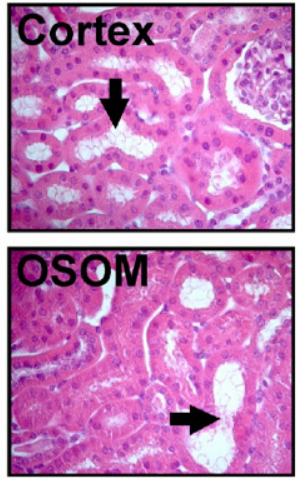

B

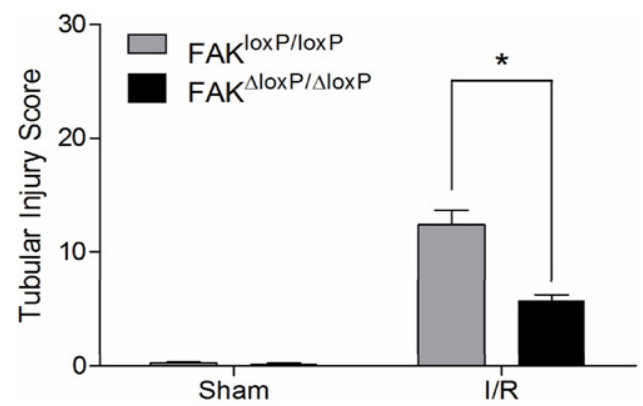

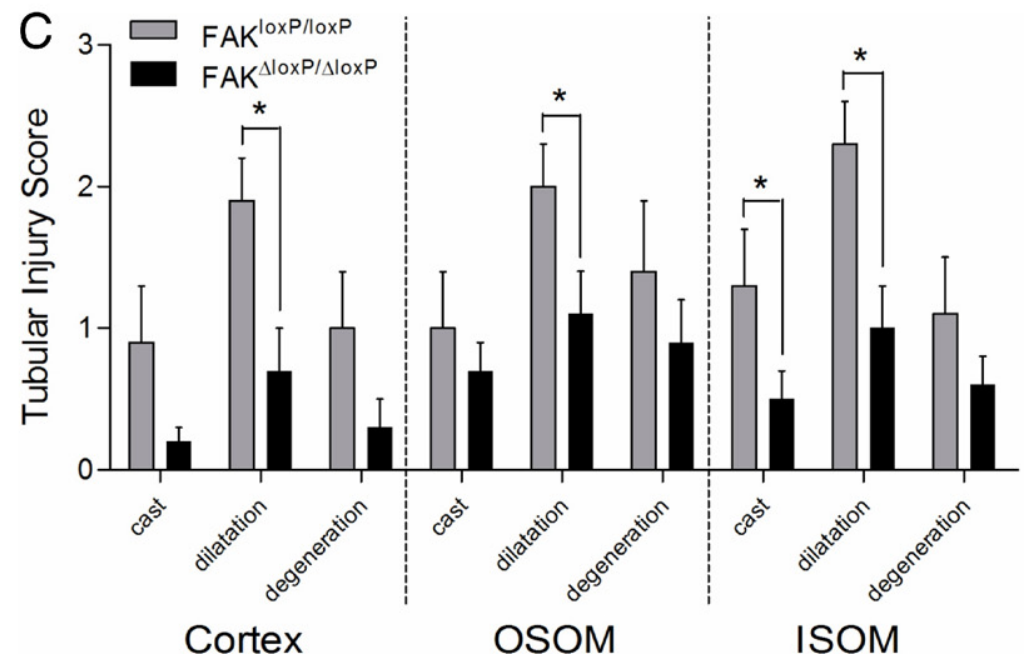

Figure 2. Histology and semiquantification of I/R-induced renal injury in FAK $\mathrm{Fl}^{\Delta \operatorname{loxP} / \Delta \operatorname{loxP}}$ and FAK ${ }^{\operatorname{loxP} / \operatorname{loxP}}$ animals. FAK ${ }^{\Delta \operatorname{loxP} / \Delta \operatorname{loxP}}$ and FAK ${ }^{\operatorname{loxP} / \operatorname{loxP}}$ animals were subjected to 35 minutes of ischemia and 24 hours of reperfusion or sham surgery. A: H\&E stainings were examined for tubular damage. Large panels: Low-magnification overview shows extensive tubular dilatation of tubule segments located in the cortical and corticomedullary areas of the kidney during $\mathrm{I} / \mathrm{R}$ injury in FAK ${ }^{\text {loxP/loxP }}$ animals but less pronounced tissue injury in FAK ${ }^{\Delta \text { loxP/AloxP }}$ animals. Sham-operated animals of both groups did not show signs of histologic injury. Small panels: High-magnification images show that tubular injury in FAK ${ }^{\text {loxP/loxP }}$ animals is present as cast deposition (indicated by asterisk), tubular dilatation (indicated by arrow), or degeneration of the tubular epithelium (indicated by open arrow). In contrast, FAK ${ }^{\Delta l o x P} / \Delta$ loxP animals only display mostly dilatation of the tubules (arrow). All images are representative for the average injury of the experimental group. Original magnification: $\times 25$ and $\times 5$; zoom $\times 400$ B-C: Tissue sections from FAK ${ }^{\Delta \operatorname{loxP} / \Delta \operatorname{loxP}}$ and FAK ${ }^{\text {loxP/loxP }}$ groups were scored double-blinded and semiquantitatively for incidence of cast, dilatation, and degeneration per region (ie, cortex, OSOM, and ISOM) to assess tubulointerstitial injury. Data are shown as total tubular injury score (B) and average score per

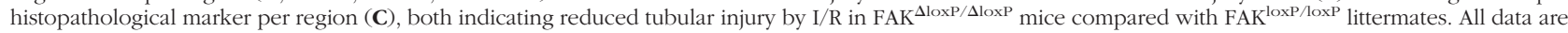
expressed as mean \pm SEM ( $n=8$ to 13 mice per group). ${ }^{*} P<0.05$. 
A

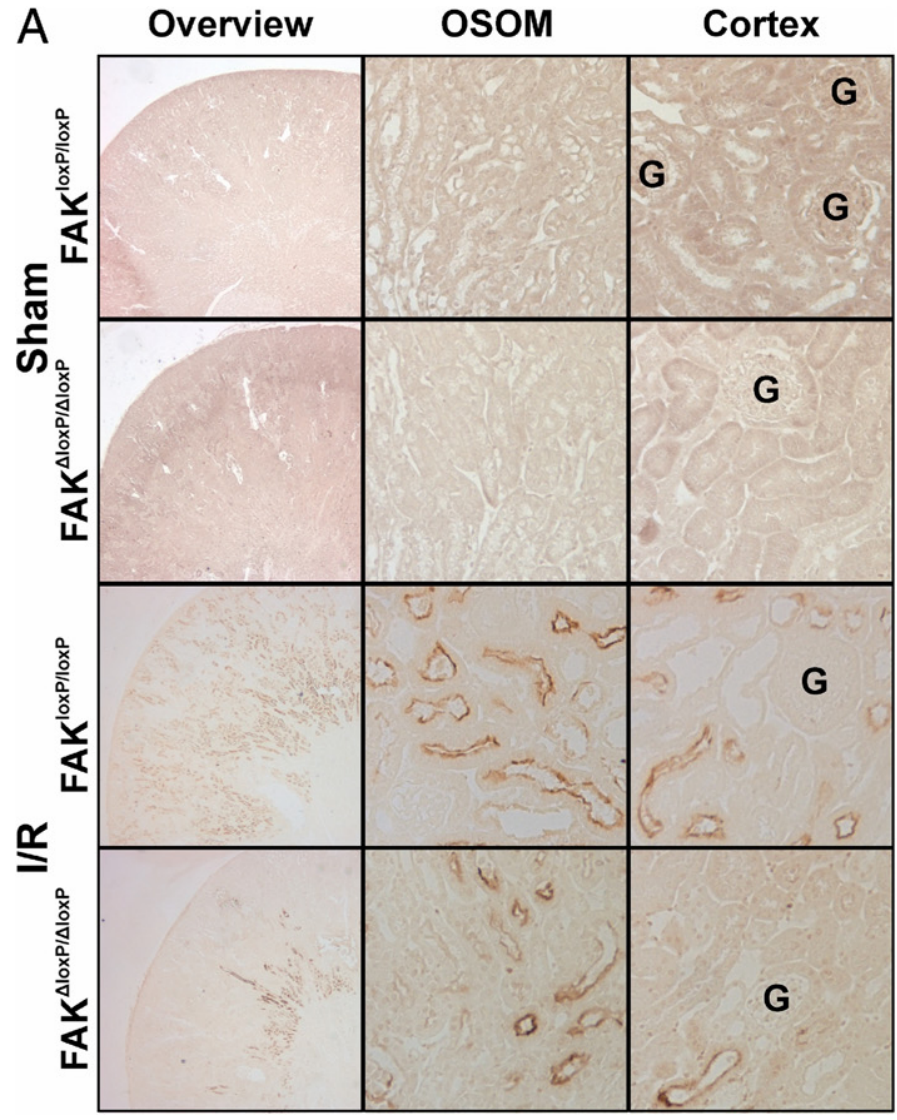

B

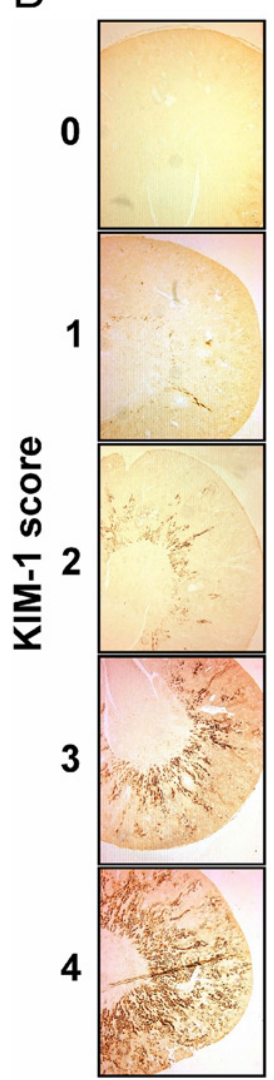

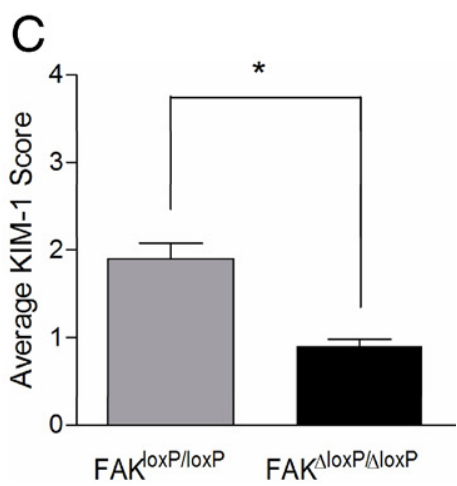

Figure 3. Less KIM-1 is expressed after $I / R$ in $\mathrm{FAK}^{\Delta \mathrm{loxP} / \Delta \operatorname{loxP}}$ mice compared with FAK ${ }^{\text {loxP/loxp }}$ littermates. A: Paraffin sections of the kidneys

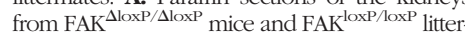
mates either subjected to 35 minutes of ischemia and 24 hours of reperfusion or sham surgery were stained for KIM-1. Images are representative for average expression of each group. G glomerulus. Original magnification: $\times 25$ and $\times 100$. B: KIM-1 expression was scored on an 0 to 4 scale that was based on the area per tissue showing specific staining as shown here. $\mathbf{C}$ : Sections were scored double-blinded for KIM-1 expression, showing that lower expression of KIM-1 was induced by $\mathrm{I} / \mathrm{R}$ in $\mathrm{FAK}^{\Delta \mathrm{loxP} / \Delta \operatorname{loxP}}$ mice compared with FAK ${ }^{\text {loxP/loxP }}$ littermates. All data are expressed as mean $\pm \operatorname{SEM}(n=8$ to 13 mice per group). ${ }^{*} P<0.05$.

\section{Proximal Tubular FAK Deficiency Reduces Tubular Injury after Renal Ischemia}

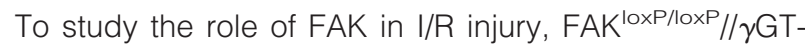
Cre-ER ${ }^{\mathrm{T2}}$ mice and control FAK ${ }^{\text {loxP/loxP }}$ littermates were treated with tamoxifen with the use of the above-described procedure and subjected to unilateral ischemia for 35 minutes followed by 24 hours of reperfusion. Kid-

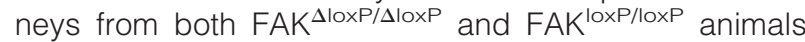
that received sham surgery were used as controls and showed no histologic indications of tubular injury in the OSOM in which the S3 segments of proximal tubules are located (Figure 2A). These findings show that fak recombination itself does not lead to tubular injury or alter tubular structure. In contrast, kidneys subjected to ischemia from $\mathrm{FAK}^{\Delta \text { loxP/DloxP }}$ and $\mathrm{FAK}^{\text {loxP/loxP }}$ animals displayed clear histologic signs of tubular damage associated with $\mathrm{I} / \mathrm{R}$ injury (Figure 2A). Tubular injury was scored semiquantitatively in the cortex, OSOM, and ISOM of the kidney on the basis of the incidence of cast deposition, tubular dilatation, and degeneration of the tubular epithelium. A significantly higher degree of tubular injury after ischemia was detected in the FAK loxP/loxP group than in the $\mathrm{FAK}^{\Delta \text { loxP/AloxP }}$ group (Figure $2 \mathrm{~B}$ ). The occurrence of tubular dilatation during I/R injury was significantly reduced in the $F A K^{\Delta \operatorname{loxP} / \Delta \operatorname{loxP}}$ animals (Figure $2 \mathrm{C}$ ).

$\mathrm{KIM}-1$ is a validated biomarker of renal parenchymal tissue injury. Expression of $\mathrm{KIM}-1$ is absent in healthy kidney tissue but is strongly up-regulated at the brush border of proximal tubules after an ischemic insult. ${ }^{19,21}$
$\mathrm{KIM}-1$ was expressed in tubules of the OSOM and cortex of FAK loxp/loxp kidneys after ischemia, whereas in the $\mathrm{FAK}^{\Delta \text { loxP/AloxP }}$ kidneys $\mathrm{KIM}-1$ was predominantly found in the proximal tubules of the OSOM only, indicating attenuated renal injury in $\mathrm{FAK}^{\Delta \operatorname{loxP} / \Delta \operatorname{loxP}}$ animals (Figure $3 \mathrm{~A}$ ). With the use of a semiquantitative scoring system for $\mathrm{KIM}-1$ staining (Figure $3 \mathrm{~B}$ ), we found that FAK ${ }^{\Delta \text { loxP/DloxP }}$ kidneys had significantly less KIM-1 staining during I/R injury than FAK ${ }^{\text {loxP/loxP }}$ kidneys (Figure $3 C$ ). These data show that loss of FAK reduces tubular injury as well as expression of KIM-1 associated with I/R injury.

Given the significantly reduced tissue injury in $\mathrm{FAK}^{\Delta \text { loxP/DloxP }}$ animals, we anticipated a decrease in the onset of tubular cell apoptosis in these animals, because apoptosis is a characteristic consequence of $\mathrm{I} / \mathrm{R}$ injury in renal tubular cells. The positive staining for cleaved caspase-3 was found significantly increased in FAK loxP/loxP kidneys subjected to I/R injury, whereas FAK ${ }^{\Delta \text { loxP/AloxP }}$ kidneys showed a trend toward a lower degree of tubular epithelial cell apoptosis (Figure 4, A and B). We also investigated the effect of proximal tubular fak deletion on post-I/R tubular cell recovery. Tubular cell proliferation is elevated after I/R injury as an initiating step of cell recovery to repair the tubular damage. With the use of Ki-67 as a cell proliferation marker, I/R injury induced high proliferation in FAK ${ }^{\text {loxP/loxP }}$ kidneys, whereas the number of Ki-67-positive cells was significantly reduced in $\mathrm{FAK}^{\Delta \text { loxP/AloxP }}$ kidneys, indicating less proliferation in $\mathrm{FAK}^{\Delta \text { loxP/AloxP }}$ animals (Figure $4, \mathrm{C}$ and D). 
A
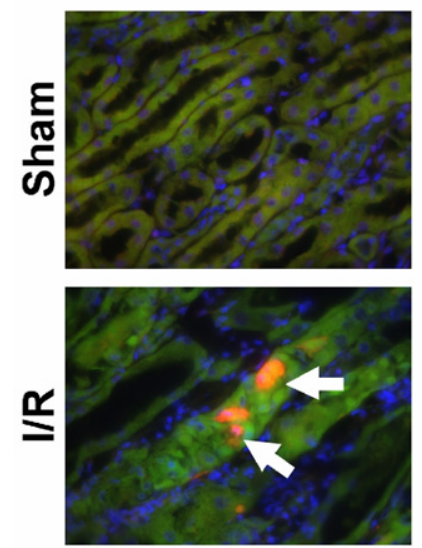

C
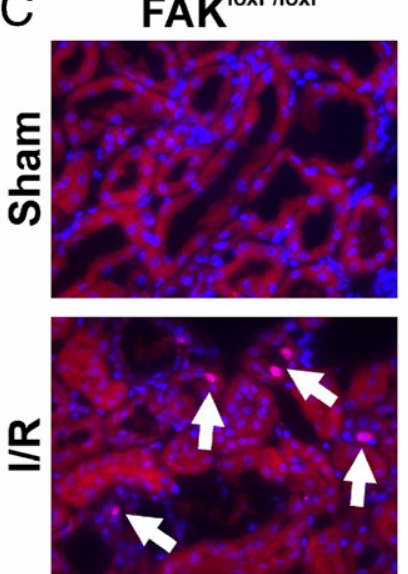

FAK $^{\Delta 10 \times P / \Delta \mid 10 \times P}$
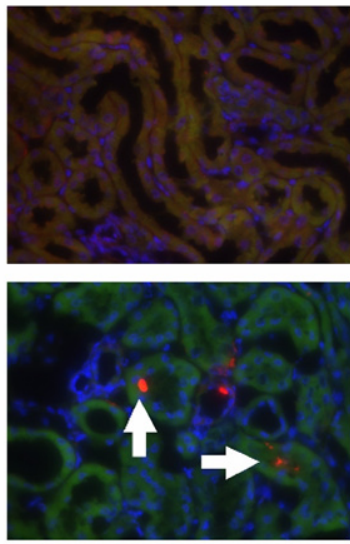

FAK
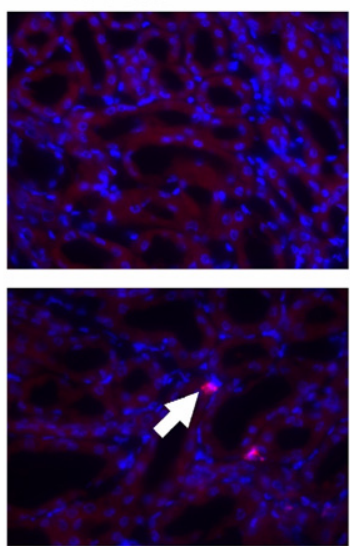

B

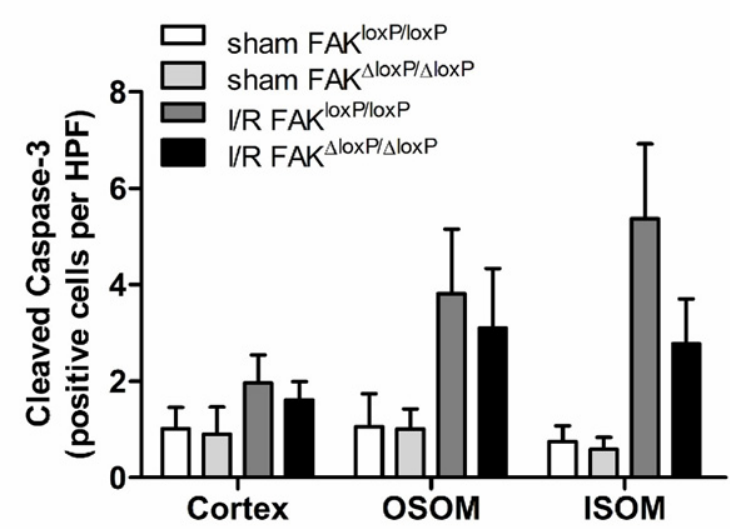

D

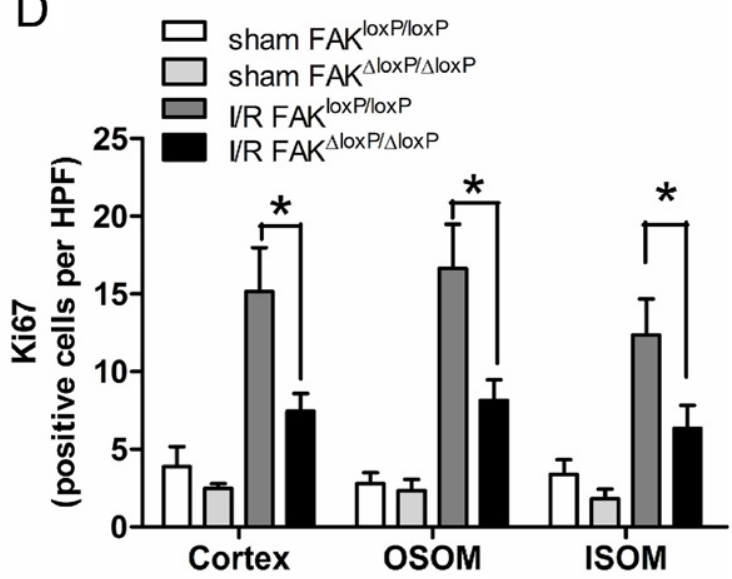

Figure 4. Immunostaining and quantification of cleaved caspase- 3 and Ki-67 in FAK $\mathrm{FloxP}^{\mathrm{l} \text { loxP }}$ and FAK ${ }^{\text {loxP/loxP }}$ animals. Cyrosections of the kidneys from

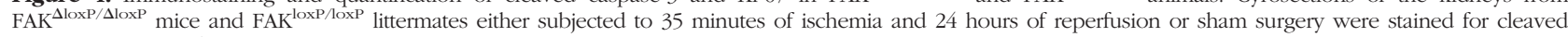
caspase-3 (A) or Ki-67 (C). Images are representative for average expression of each group (indicated by arrows). Original magnification: $\times 40$. For each section, 5 to 10 different fields in the cortex, OSOM, and ISOM were analyzed to count the number of cleaved caspase-3-positive (B) or Ki-67-positive (D) cells in each region, and the average number of each group was expressed as the number of positive cells per high-power field (HPF). Results indicate a trend toward less cleaved caspase-3 staining and significantly reduced $\mathrm{Ki}-67$ staining in FAK ${ }^{\Delta \text { loxP/AloxP }}$ mice compared with FAK ${ }^{\text {loxP/loxP }}$ littermates. Data are expressed as mean \pm SEM $\left(n=8\right.$ to 13 mice per group). ${ }^{*} P<0.05$.

\section{Expression of FAK Does Not Regulate Renal Inflammation during I/R Injury}

Expression of pro-inflammatory chemokines by proximal tubular epithelium is a critical factor in the regulation of immune cell infiltration in the kidney during $\mathrm{l} / \mathrm{R}$ injury ${ }^{22}$ and was found to be dependent on NF- $\kappa$ B activation. ${ }^{23}$ Recent studies have shown involvement of FAK in the regulation of NF- $\kappa$ B. ${ }^{14,24}$ Because the extent of the inflammatory response is correlated to the extent of tubular injury during $\mathrm{l} / \mathrm{R}$ injury, we performed immunostaining for the pan-leukocyte marker CD45 and the macrophage marker F4/80 to determine whether FAK deficiency also reduced the accumulation of inflammatory cells after renal ischemia. However, no significant difference in the number of CD45- and F4/80-expressing cells was found between kidneys from FAK ${ }^{\operatorname{loxP} / \mathrm{loxP}}$ and $\mathrm{FAK}^{\Delta \operatorname{loxP} / \Delta \operatorname{loxP}}$ animals after ischemia (see Supplemental Figure S2 at http://ajp.amjpathol.org).

To confirm our in vivo finding that FAK is not involved in the regulation of the inflammatory response after ischemia, we examined chemokine/cytokine production in primary cultured FAK-expressing and FAK-deficient tubular epithelial cells. Cells were subjected to $\mathrm{H}_{2} \mathrm{O}_{2}$ to mimic the in vivo biochemical perturbation caused by the oxidative stress associated with reperfusion after renal ischemia. ${ }^{4}$ Culture medium samples were collected to determine the release of IL-6 and MCP-1. Although $\mathrm{H}_{2} \mathrm{O}_{2}$ caused a time-dependent increase in both IL-6 and MCP-1 levels, no difference between FAK-expressing and FAK-deficient cells was observed (see Supplemental Figure S3 at http://ajp.amjpathol.org). These results suggest that modulation of FAK expression does not influence pro-inflammatory cytokine production in vitro and does not result in alterations in immune cell infiltration in our in vivo model.

\section{Loss of FAK Reduces the Rate of Focal Adhesion Recovery after Oxidative Stress}

We have demonstrated that I/R injury modulates FA restructuring dynamics and phosphorylation of FAK. ${ }^{5}$ These findings indicated that FAK plays a critical role in 
establishing recovery of cell adhesion during I/R injury. To provoke FA disruption we exposed primary cultured renal cells to $\mathrm{H}_{2} \mathrm{O}_{2}$ to mimic oxidative stress, an important in vivo biochemical cellular perturbation component during reperfusion. FAs were identified at different time points by immunostaining for the FA protein vinculin (Figure $5 \mathrm{~A}$ ). Analysis of culture supernatant fluid that was collected at each time point and analyzed for LDH release showed that no significant cell killing occurs after 8 hours of $\mathrm{H}_{2} \mathrm{O}_{2}$ exposure and that there is no difference in cell death between $\mathrm{FAK}^{\text {loxP/loxP }}$ and $F \mathrm{FK}^{\Delta \text { loxP/DloxP }}$ cells during exposure (see Supplemental Figure $S 4$ at http:// ajp.amjpathol.org). After 2 hours of exposure to $\mathrm{H}_{2} \mathrm{O}_{2}$, a $40 \%$ decrease in the number of FAs occurred in both FAK-expressing and FAK-deficient cells (Figure 5B). Recovery of the FA organization started after 2 hours but was slightly delayed in FAK-deficient cells and accompanied by a shape change in FAs compared with that in FAK-expressing cells (Figure 5, A and B). This suggests that the loss of FAK increases the stability of FAs during recovery and is in accordance with previous studies reporting a similar effect of FAK deficiency on increased FA size. ${ }^{25}$

\section{FAK Facilitates Activation of JNK-Associated FA Recovery via Phosphorylation of Ser178 Paxillin}

Oxidative stress-induced cell injury during I/R injury involves activation of the stress kinase JNK. ${ }^{26,27}$ JNK phosphorylates the FA adapter protein paxillin at serine residue 178 (Ser178). ${ }^{28}$ Because FAK is necessary for normal FA turnover, this paxillin phosphorylation site can recruit $F A K$ and therefore is critical for regulation of $F A$ dynamics. ${ }^{29}$ We hypothesized that loss of FAK might affect the activation of JNK pathway as well as its interaction with paxillin signaling and, ultimately, affect the FA dynamics after oxidative stress in tubular epithelial cells. We found that $\mathrm{H}_{2} \mathrm{O}_{2}$ induced phosphorylation of JNK and its kinase substrate c-Jun after 30 minutes of exposure (Figure 6, A and B), which was associated with an in-

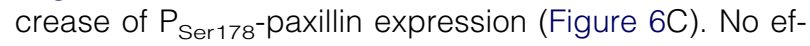
fect of $\mathrm{H}_{2} \mathrm{O}_{2}$ was observed on either $\mathrm{P}_{\mathrm{Tyr397}}$-FAK (Figure

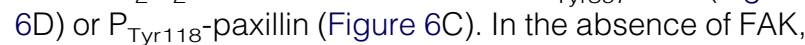
phosphorylation of $\mathrm{JNK}$ by $\mathrm{H}_{2} \mathrm{O}_{2}$ was significantly decreased (Figure 6A), which coincided with reduced phosphorylation of C-Jun (Figure 6B) as well as reduced

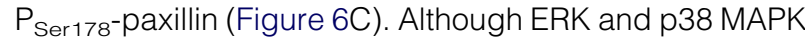
phosphorylation occurred during in vitro oxidative stress, no difference was observed in the level of phosphorylation of both kinases between FAK-expressing and FAKdeficient cells (data not shown).

Under control conditions little $\mathrm{P}_{\text {Ser178-paxillin was ob- }}$ served at FAs, whereas $\mathrm{H}_{2} \mathrm{O}_{2}$ exposure resulted in a rapid increase in $\mathrm{P}_{\text {ser178-paxillin at these sites with colo- }}$ calization of vinculin (Figure 7A). In FAK-deficient cells however, $P_{\text {Ser178-paxillin phosphorylation during oxida- }}$ tive stress was found to be much weaker (Figure 7B). In FAK-expressing cells the number of cells with FAs that

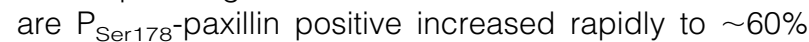
after 2 hours of $\mathrm{H}_{2} \mathrm{O}_{2}$ exposure, whereas this number was
A FAK $^{\text {loxPlloxP }}$ FAK $^{\Delta l o x P / \Delta l o x P}$

0
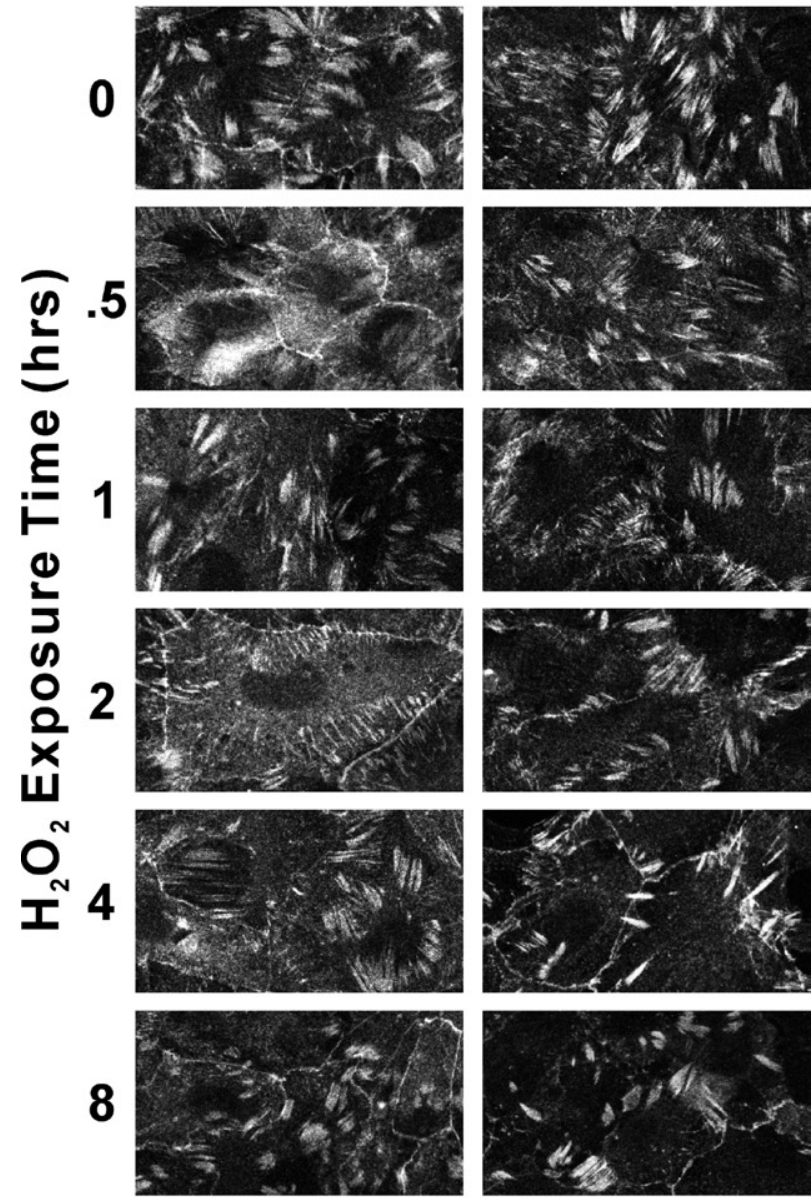

B

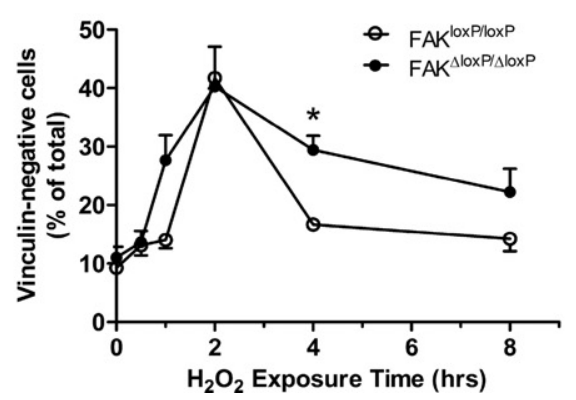

Figure 5. FAK mediates FA recovery after $\mathrm{H}_{2} \mathrm{O}_{2}$ exposure. FAK-expressing and FAK-deficient $\left(\mathrm{FAK}^{\mathrm{loxP} / \mathrm{loxP}}\right.$ and $\mathrm{FAK}^{\Delta \operatorname{loxP} / \Delta \operatorname{loxP}}$, respectively) primary renal cells were cultured on coverslips and treated with $1 \mathrm{mmol} / \mathrm{L} \mathrm{H}_{2} \mathrm{O}_{2}$ for indicated time periods. A: The location of FAs was analyzed by immunofluorescent staining for vinculin and followed by confocal laser scanning microscopic analysis. Magnified images show shape changes in FAs during exposure. Original magnification: $\times 60$. B: For each condition and time point, five different fields on each coverslip were analyzed to quantify the percentage of vinculin-negative cells. Results indicate a slower recovery of FA after 2 hours of $\mathrm{H}_{2} \mathrm{O}_{2}$ exposure in FAK-deficient cells compared with FAK-expressing cells. Data are expressed as mean $\pm \operatorname{SEM}(n=3) .{ }^{*} P<0.05$, significant difference between FAK ${ }^{\operatorname{loxP} / \text { loxP }}$ and FAK ${ }^{\Delta \text { loxP/DloxP }}$ cells.

significantly lower in FAK-deficient cells (Figure 7, B and C). These results indicate that resident JNK/P $P_{\text {Ser178-pax- }}$ illin signaling, which is involved in FA assembly in response to oxidative stress, is impaired in FAK-deficient cells. 

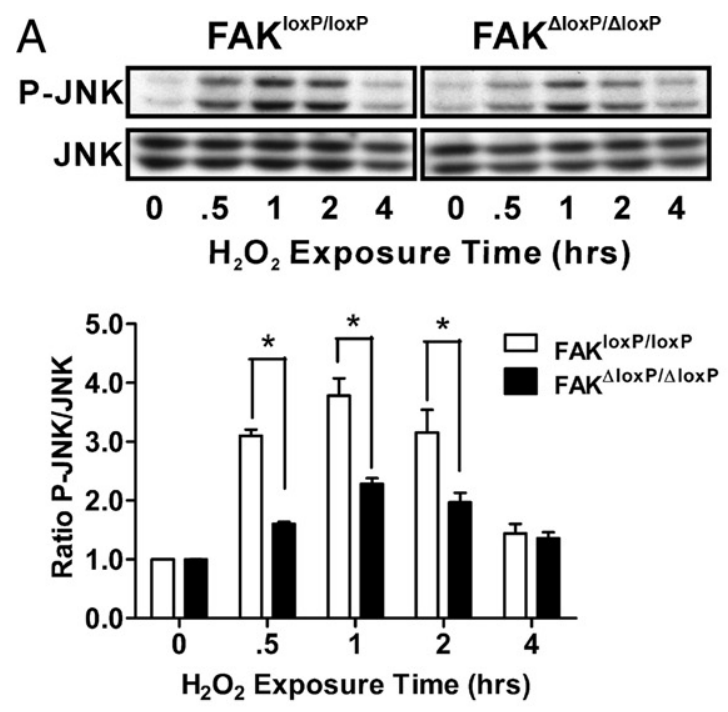

C
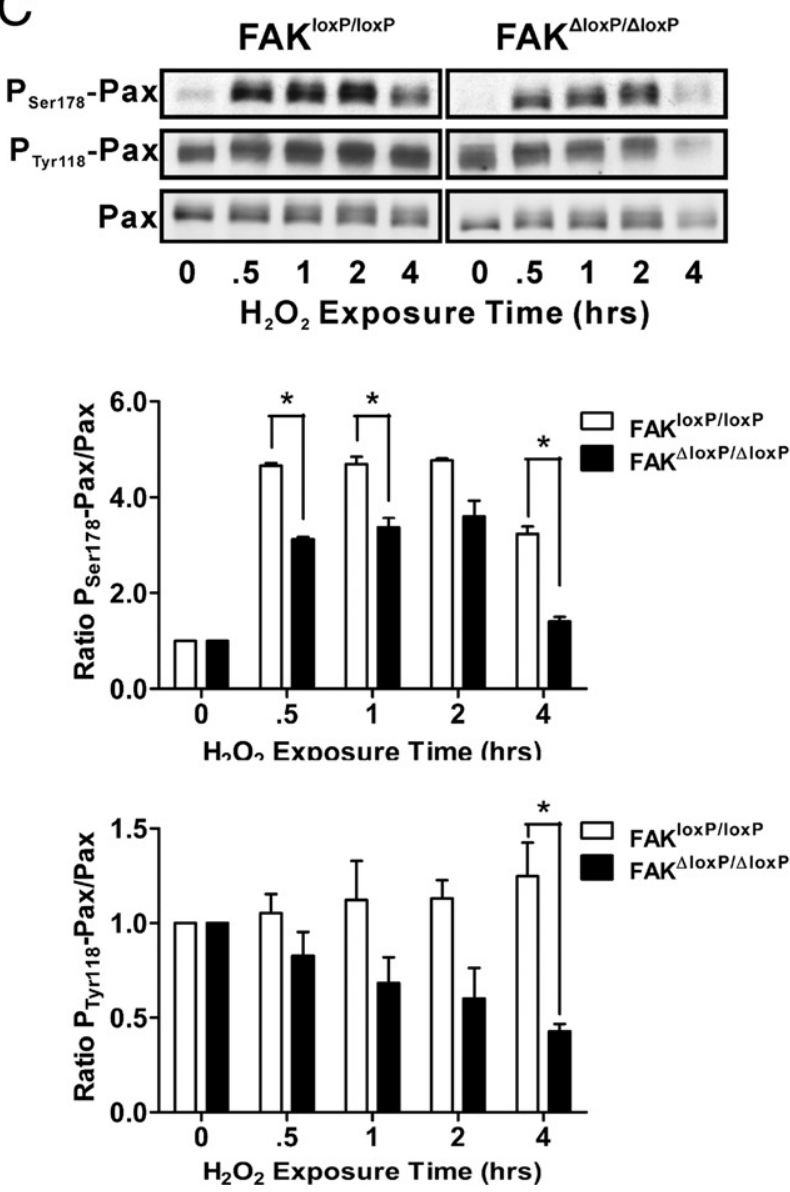

\section{Discussion}

In this study we investigated the role of FAK in renal I/R injury with the use of selective and conditional deletion of fak in proximal tubules. We find that proximal tubule-specific deletion of fak protects against I/R-induced renal injury by decreasing tubular damage, which is associated with a decrease in KIM-1 expression and tubular cell proliferation. Our in vitro studies
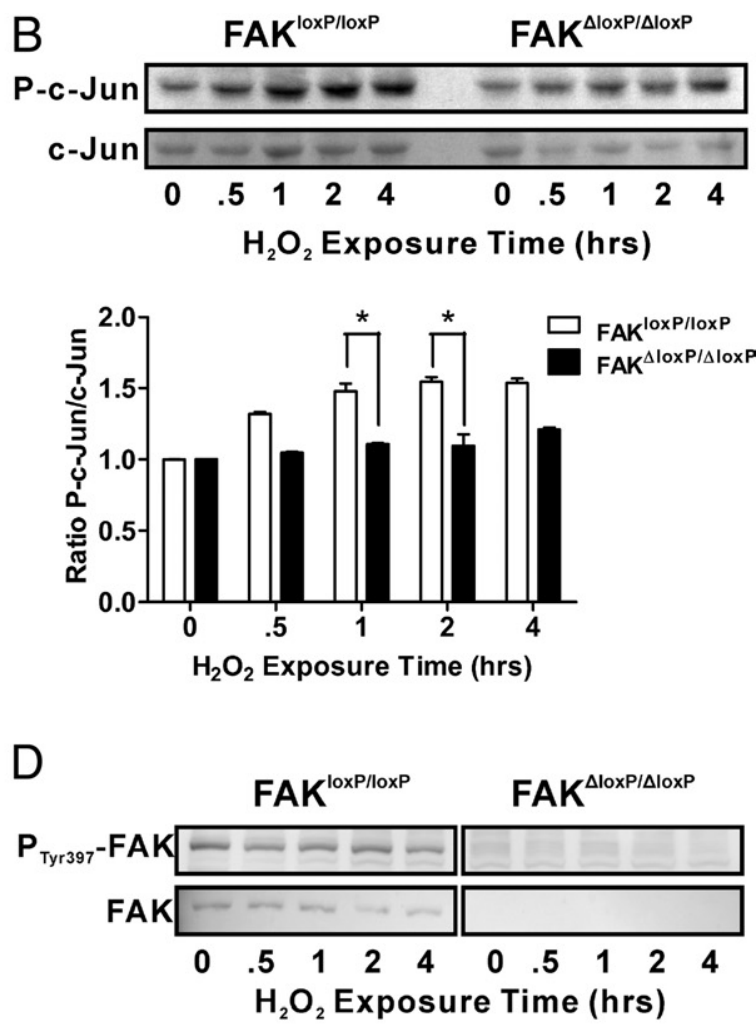

Figure 6. FAK mediates JNK-dependent serine phosphorylation of paxillin after $\mathrm{H}_{2} \mathrm{O}_{2}$ exposure. FAK-expressing and FAK-deficient (FAK ${ }^{\text {loxP/lox }}$ and $\mathrm{FAK}^{\Delta \mathrm{LxP} / \Delta \mathrm{loxP}}$, respectively) primary renal cells were exposed to 1 $\mathrm{mmol} / \mathrm{L} \mathrm{H}_{2} \mathrm{O}_{2}$ for indicated time periods. Phosphorylation of $\mathrm{P}_{\mathrm{Thr} 183}$ $\mathrm{P}_{\text {Tyr185-JNK }}(\mathbf{A}), \mathrm{P}_{\text {Ser63-C-Jun }}(\mathbf{B}), \mathrm{P}_{\text {Ser178-paxillin and }} \mathrm{P}_{\text {Tyr118-paxillin }}$ (C), and $\mathrm{P}_{\mathrm{Tyr} 397}$-FAK (D) was determined with phospho-specific antibodies. Western blot analyses show less activation of $\mathrm{JNK} / \mathrm{P}_{\text {Ser178 }}$ paxillin signaling in FAK-deficient cells during $\mathrm{H}_{2} \mathrm{O}_{2}$-induced oxidative stress and are representative of three independent experiments. Densitometric analysis of the blots determined the ratio between phosphorylated and total protein (arbitrary units). Data are expressed as mean $\pm \operatorname{SEM}(n=3) .{ }^{*} P<0.05$ show that oxidative stress-associated signaling is involved in the dynamic turnover of FAs and that this process is impaired in FAK-deficient cells. This is reflected by a reduced activation of the stress kinase JNK and the subsequent phosphorylation of the FA-associated adapter protein paxillin at Ser178.

Genetic fak knockout mice display embryonic lethality (at embryonic day 8.5). ${ }^{15}$ Because of its ubiquitous ex- 
A
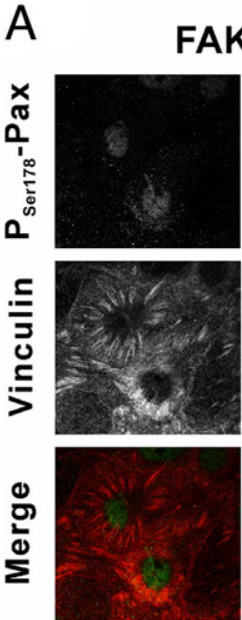

0
FAK ${ }^{\text {loxPIloxP }}$
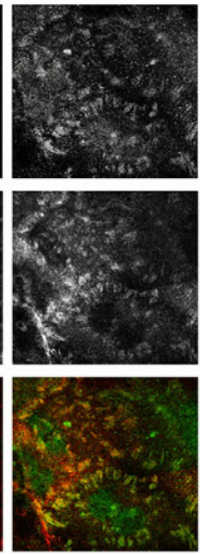

2
FAK SloxPIDIoxP $^{\Delta}$
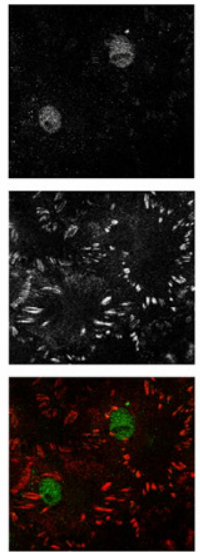

0
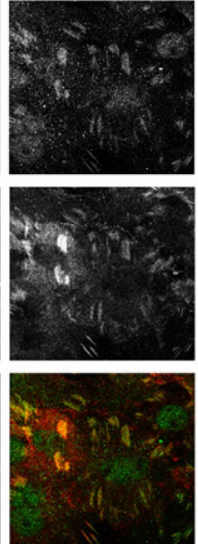

2

$\mathrm{H}_{2} \mathrm{O}_{2}$ Exposure Time (hrs)

C

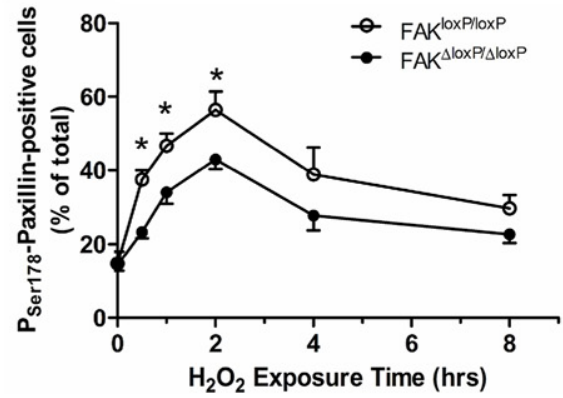

B

BAK ${ }^{\text {I0xPlloxp }}$

5
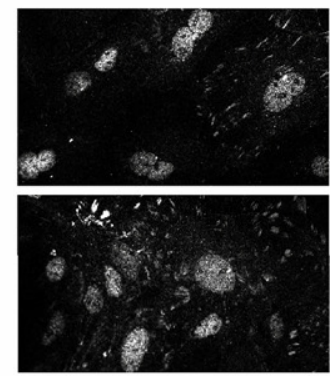

1

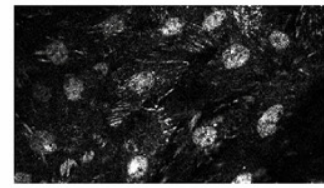

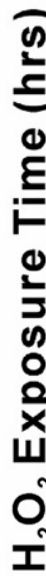

2

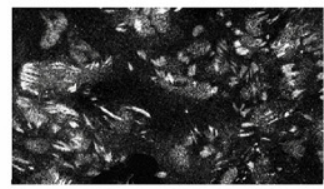

$\stackrel{O}{N}^{N} 4$
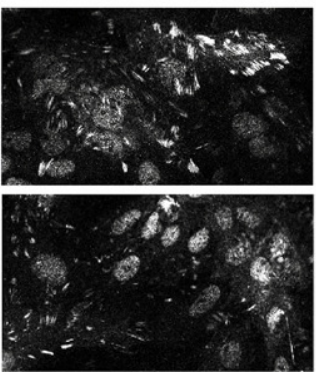

FAK ${ }^{\Delta l o x P / \Delta l o x P}$
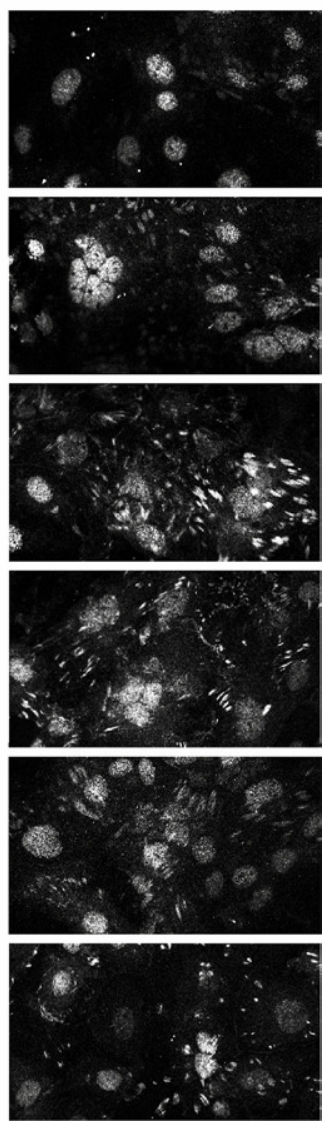

Figure 7. FAK mediates serine phosphorylation of paxillin at FAs after $\mathrm{H}_{2} \mathrm{O}_{2}$ exposure. FAK-expressing and FAK-deficient (FAK ${ }^{\text {loxP/loxP }}$ and FAK ${ }^{\Delta l o x P} / \Delta$ loxP respectively) primary renal cells were cultured on coverslips and treated with $1 \mathrm{mmol} / \mathrm{L} \mathrm{H}_{2} \mathrm{O}_{2}$ for indicated time periods. A: The location of serine-phosphorylated paxillin and FAs after 2-hour exposure was analyzed by immunofluorescent staining of $\mathrm{P}_{\text {Ser178-paxillin and vinculin, respectively, and followed by confocal laser }}$ scanning microscopic analysis. Representative images show the colocalization of vinculin (red) and $\mathrm{H}_{2} \mathrm{O}_{2}$-induced $\mathrm{P}_{\mathrm{Ser} 178}$-paxillin (green). Original magnification:

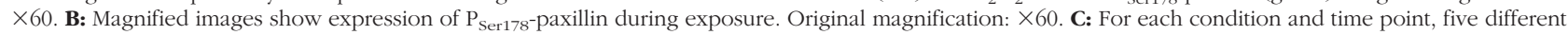

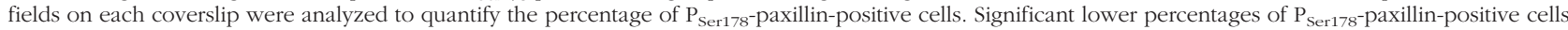
were detected in the FAK-deficient group from 30 minutes to 2 hours of $\mathrm{H}_{2} \mathrm{O}_{2}$ exposure, which is consistent with the observation from Western blot analysis. Data are expressed as mean $\pm \operatorname{SEM}(n=3) .{ }^{*} P<0.05$, significant difference between FAK ${ }^{\text {loxP/loxP }}$ and $\mathrm{FAK}^{\Delta \operatorname{loxP} / \Delta \operatorname{loxP}}$ cells.

pression pattern, deletion of fak in adulthood will result in a complex knockout phenotype in the context of I/R injury affecting tubular epithelial, endothelial, and inflammatory cell function. For example, FAK deficiency impaired pathogen-killing and decreased lifespan of neutrophils. ${ }^{30}$ Nonspecific knockdown after systemic administration of small interfering RNA targeting FAK in mice resulted in tissue insulin resistance. ${ }^{31}$ Therefore, tissue-orientated Cre/LoxP system was used to induce a spatially conditional knockout of fak in the mouse. ${ }^{16,17}$ It was observed in our experiments that, although tamoxifen administration induced complete multiorgan fak recombination and significant reduction of renal FAK expression in $\mathrm{FAK}^{\text {loxP/loxP//Rosa-Cre-ER }}{ }^{\mathrm{T} 2}$ mice, the same treatment only resulted in partial renal fak recombination and exclusively proximal tubular FAK deficiency in FAK ${ }^{\text {loxP/loxP// }}$ $\gamma$ GT-Cre-ER ${ }^{\text {T2 }}$ mice. Nevertheless, to eliminate the potential effects of fak knockout on renal physiology as well as individual knockout mouse variability, the unilateral ischemia model was used in our experiments whereby the contralateral kidney from each animal was used as an internal control for injury. Because I/R injury predomi- nantly affects cells of the proximal tubules, ${ }^{32}$ we aimed to study the role of FAK specifically in this segment of the nephron.

FAK deficiency significantly protected against renal injury on the basis of various injury markers. This suggests that FAK signaling is involved in the pathophysiology of I/R-induced acute renal failure. It fits our previous observation that FAK undergoes dephosphorylation directly after ischemia and thereafter is differentially hyperphosphorylated at different phosphorylation sites during the reperfusion phase. ${ }^{5} \mathrm{KIM}-1$ expression is an early marker of cellular injury that is specific for the proximal tubular cells and is induced by different types of injuries, including I/R injury. ${ }^{19}$ Because FAK deficiency reduced I/R-caused KIM-1 up-regulation, cell proliferation elevation, as well as renal tissue damage, we anticipated that the lack of FAK also alleviates the cellular stress response that is otherwise driven by the hyperphosphorylation of FAK during reperfusion.

In vitro studies have shown a central role for FAK in different cellular signaling pathways such as cell stress signaling, ${ }^{28}$ survival, ${ }^{12}$ and proliferation ${ }^{13}$ next to its role 
in controlling cell adhesion dynamics ${ }^{10}$ and regulating $\mathrm{NF}-\kappa \mathrm{B}-\mathrm{mediated}$ expression of pro-inflammatory factors. ${ }^{14}$ However, establishing the role of FAK in tissue injury in vivo has been hampered by the difficulty to induce spatiotemporal knockdown of FAK expression. A recent study that used inducible, myocyte-specific knockdown of FAK showed a role for FAK in NF- $\kappa$ Bdependent cell survival after myocardial infarction and the reduction of infarction size in control animals compared with mice with FAK-deficient myocytes. ${ }^{33}$

Here, we propose a role for FAK in the initiation of tubular epithelial cell stress next to the control of dynamic $F A$ reorganization. The in vivo results that FAK deficiency alleviated tubular damage, KIM-1 expression, and tubular cell proliferation during I/R injury, but did not affect inflammatory cell influx, suggest that tubular epithelial cell stress rather than renal inflammation is mediated by FAK. We did not examine whether FAK deficiency of the proximal tubular epithelium alters macrophage subset polarization by induction of differential expression of proinflammatory cytokines. ${ }^{34}$ However, because macrophage influx significantly increases at day 3 after ischemia and peaks at day $7,{ }^{35}$ the involvement of macrophage in the injury process studied here may be expected to be restricted to a minimum. We were able to mimic the in vivo biochemical perturbation caused by the oxidative stress associated with reperfusion after renal ischemia with the use of $\mathrm{H}_{2} \mathrm{O}_{2}$ exposure on primary renal cells, although in vivo oxidants are usually composed of a variety of species. Previous studies have shown that reactive oxygen species mediates FA complex disassembly accompanied by FAK dephosphorylation and weakens FA-mediated cell matrix adhesion of tubular epithelial cells. ${ }^{4}$ We confirmed that $\mathrm{H}_{2} \mathrm{O}_{2}$ profoundly impaired FA stability by initiating FA turnover in both FAK-expressing and FAK-deficient cells. Although NF- $\kappa$ B-mediated expression of MCP-1 and IL- $6^{36}$ increased in response to $\mathrm{H}_{2} \mathrm{O}_{2}$ exposure, this was independent of FAK expression. Whether oxidative stress is the critical component in regulating FA disturbance in vivo during renal $I / R$ injury needs further investigation.

The stress kinase JNK is an important player in the cellular stress response to injury and is activated during $\mathrm{I} / \mathrm{R}$ in vivo. ${ }^{26,37}$ Interestingly, our data showed that FAK deficiency suppressed oxidative stress-induced activation of JNK in renal cells. This is consistent with a model in which the protection against renal injury is because of reduced JNK activation. ${ }^{38}$ We have previously demonstrated that active phosphorylated JNK is localized at FAs in renal cells on chemical-induced injury. ${ }^{38}$ Previous studies also suggest a physical association between FAK and JNK via the adaptor protein JIP3. ${ }^{39}$ FAK may therefore target JNK to FAs during oxidative stress, contributing to its localized activation and stress signaling. There is increasing evidence that JNK plays an important role in controlling FA dynamics. ${ }^{28}$ These findings point to an interplay between FAK, JNK, and control of FA dynamics and a role for these proteins in the stress response during tubular epithelial injury.

Pharmacologic modulation of FAK activity in the kidney may represent a valid strategy to protect against I/R- induced renal failure. FAK inhibitors have been studied for their potential as anticancer therapy and might therefore be "repurposed." ${ }^{0}$

In conclusion, our data indicate a role for FAK signaling in proximal tubules during progression of $\mathrm{I} / \mathrm{R}$-induced acute renal injury. We propose a model whereby FAK is required for recruitment of JNK to FAs leading to JNKmediated phosphorylation of paxillin at Ser178, thereby facilitating FA turnover during oxidative stress. This FAK/ $\mathrm{JNK} /$ paxillin linkage could potentially be the basis for future targets for therapeutic intervention in acute renal failure.

\section{Acknowledgments}

We thank Annemieke van der Wal and Reshma Lalai for their expert technical assistance.

\section{References}

1. Hoste EA, Schurgers M: Epidemiology of acute kidney injury: how big is the problem? Crit Care Med 2008, 36:S146-S151

2. Racusen LC, Fivush BA, Li YL, Slatnik I, Solez K: Dissociation of tubular cell detachment and tubular cell death in clinical and experimental "acute tubular necrosis". Lab Invest 1991, 64:546-556

3. Zuk A, Bonventre JV, Brown D, Matlin KS: Polarity, integrin, and extracellular matrix dynamics in the postischemic rat kidney. Am J Physiol 1998, 275:C711-C731

4. Saenz-Morales D, Escribese MM, Stamatakis K, Garcia-Martos M, Alegre L, Conde E, Perez-Sala D, Mampaso F, Garcia-Bermejo ML: Requirements for proximal tubule epithelial cell detachment in response to ischemia: role of oxidative stress. Exp Cell Res 2006, 312:3711-3727

5. Alderliesten M, de Graauw M, Oldenampsen J, Qin Y, Pont C, van Buren L, van de Water B: Extracellular signal-regulated kinase activation during renal ischemia/reperfusion mediates focal adhesion dissolution and renal injury. Am J Pathol 2007, 171:452-462

6. Berrier AL, Yamada KM: Cell-matrix adhesion. J Cell Physiol 2007, 213:565-573

7. Harburger DS, Calderwood DA: Integrin signalling at a glance. J Cell Sci 2009, 122:159-163

8. Kellerman PS, Clark RA, Hoilien CA, Linas SL, Molitoris BA: Role of microfilaments in maintenance of proximal tubule structural and functional integrity. Am J Physiol 1990, 259:F279-F285

9. Weinberg JM, Venkatachalam MA, Roeser NF, Senter RA, Nissim I: Energetic determinants of tyrosine phosphorylation of focal adhesion proteins during hypoxia/reoxygenation of kidney proximal tubules. Am J Pathol 2001, 158:2153-2164

10. Webb DJ, Donais K, Whitmore LA, Thomas SM, Turner CE, Parsons JT, Horwitz AF: FAK-Src signalling through paxillin. ERK and MLCK regulates adhesion disassembly, Nat Cell Biol 2004, 6:154-161

11. Schlaepfer DD, Hauck CR, Sieg DJ: Signaling through focal adhesion kinase. Prog Biophys Mol Biol 1999, 71:435-478

12. Zouq NK, Keeble JA, Lindsay J, Valentijn AJ, Zhang L, Mills D, Turner $\mathrm{CE}$, Streuli $\mathrm{CH}$, Gilmore AP: FAK engages multiple pathways to maintain survival of fibroblasts and epithelia: differential roles for paxillin and p130Cas. J Cell Sci 2009, 122:357-367

13. Lim ST, Chen XL, Lim Y, Hanson DA, Vo TT, Howerton K, Larocque N, Fisher SJ, Schlaepfer DD, Ilic D: Nuclear FAK promotes cell proliferation and survival through FERM-enhanced p53 degradation. Mol Cell 2008, 29:9-22

14. Funakoshi-Tago M, Sonoda $\mathrm{Y}$, Tanaka S, Hashimoto K, Tago K, Tominaga S, Kasahara T: Tumor necrosis factor-induced nuclear factor kappaB activation is impaired in focal adhesion kinase-deficient fibroblasts. J Biol Chem 2003, 278:29359-29365

15. Ilic D, Furuta Y, Kanazawa S, Takeda N, Sobue K, Nakatsuji N, Nomura S, Fujimoto J, Okada M, Yamamoto T: Reduced cell motility and enhanced focal adhesion contact formation in cells from FAKdeficient mice. Nature 1995, 377:539-544 
16. Beggs HE, Schahin-Reed D, Zang K, Goebbels S, Nave KA, Gorski J, Jones KR, Sretavan D, Reichardt LF: FAK deficiency in cells contributing to the basal lamina results in cortical abnormalities resembling congenital muscular dystrophies. Neuron 2003, 40:501-514

17. Dworniczak B, Skryabin B, Tchinda J, Heuck S, Seesing FJ, Metzger D, Chambon P. Horst J, Pennekamp P: Inducible Cre/loxP recombination in the mouse proximal tubule. Nephron Exp Nephrol 2007, 106:e11-e20

18. Vooijs $\mathrm{M}$, Jonkers J, Berns A: A highly efficient ligand-regulated Cre recombinase mouse line shows that LoxP recombination is position dependent. EMBO Rep 2001, 2:292-297

19. Ichimura T, Bonventre JV, Bailly V, Wei H, Hession CA, Cate RL, Sanicola M: Kidney injury molecule-1 (KIM-1), a putative epithelial cell adhesion molecule containing a novel immunoglobulin domain, is up-regulated in renal cells after injury. J Biol Chem 1998, 273:4135-4142

20. Chen Q, Jones TW, Brown PC, Stevens JL: The mechanism of cysteine conjugate cytotoxicity in renal epithelial cells. Covalent binding leads to thiol depletion and lipid peroxidation. J Biol Chem 1990, 265:21603-21611

21. Vaidya VS, Ramirez V, Ichimura T, Bobadilla NA, Bonventre JV: Urinary kidney injury molecule-1: a sensitive quantitative biomarker for early detection of kidney tubular injury. Am J Physiol Renal Physiol 2006, 290:F517-F529

22. Daha MR, van Kooten C: Is the proximal tubular cell a proinflammatory cell? Nephrol Dial Transplant 2000, 15(Suppl 6):41-43

23. Cao CC, Ding XQ, Ou ZL, Liu CF, Li P, Wang L, Zhu CF: In vivo transfection of NF-kappaB decoy oligodeoxynucleotides attenuate renal ischemia/reperfusion injury in rats. Kidney Int 2004, 65:834-845

24. Huang D, Khoe M, Befekadu M, Chung S, Takata Y, llic D, Bryer-Ash M: Focal adhesion kinase mediates cell survival via NF-kappaB and ERK signaling pathways. Am J Physiol Cell Physiol 2007, 292:C1339-C1352

25. van Miltenburg $\mathrm{MH}$, Lalai $\mathrm{R}$, de Bont $H$, van Waaij $\mathrm{E}$, Beggs $H$, Danen $\mathrm{EH}$, van de Water B: Complete focal adhesion kinase deficiency in the mammary gland causes ductal dilation and aberrant branching morphogenesis through defects in Rho kinase-dependent cell contractility. FASEB J 2009, 23:3482-3493

26. Lee KH, Kim SE, Lee YS: SP600125, a selective JNK inhibitor, aggravates hepatic ischemia-reperfusion injury. Exp Mol Med 2006 , 38:408-416

27. DiMari J, Megyesi J, Udvarhelyi N, Price P, Davis R, Safirstein R: $\mathrm{N}$-acetyl cysteine ameliorates ischemic renal failure. Am J Physiol 1997, 272:F292-F298

28. Huang C, Rajfur Z, Borchers C, Schaller MD, Jacobson K: JNK phosphorylates paxillin and regulates cell migration. Nature 2003, 424:219-223
29. Huang Z, Yan DP, Ge BX: JNK regulates cell migration through promotion of tyrosine phosphorylation of paxillin. Cell Signal 2008, 20:2002-2012

30. Kasorn A, Alcaide P, Jia Y, Subramanian KK, Sarraj B, Li Y, Loison F, Hattori H, Silberstein LE, Luscinskas WF, Luo HR: Focal adhesion kinase regulates pathogen-killing capability and life span of neutrophils via mediating both adhesion-dependent and -independent cellular signals. J Immunol 2009, 183:1032-1043

31. Bisht B, Srinivasan K, Dey CS: In vivo inhibition of focal adhesion kinase causes insulin resistance. J Physiol 2008, 586:3825-3837

32. Bonventre JV: Mechanisms of ischemic acute renal failure. Kidney Int 1993, 43:1160-1178

33. Hakim ZS, DiMichele LA, Rojas M, Meredith D, Mack CP, Taylor JM: FAK regulates cardiomyocyte survival following ischemia/reperfusion. J Mol Cell Cardiol 2009, 46:241-248

34. Werno C, Menrad H, Weigert A, Dehne N, Goerdt S, Schledzewski K, Kzhyshkowska J, Brune B: Knockout of HIF-1alpha in tumor-associated macrophages enhances M2 polarization and attenuates their pro-angiogenic responses. Carcinogenesis 2010, 31:1863-1872

35. Stokman G, Leemans JC, Claessen N, Weening JJ, Florquin S: Hematopoietic stem cell mobilization therapy accelerates recovery of renal function independent of stem cell contribution. J Am Soc Nephrol 2005, 16:1684-1692

36. Sanz AB, Sanchez-Nino MD, Ramos AM, Moreno JA, Santamaria B, Ruiz-Ortega M, Egido J, Ortiz A: NF-kappaB in renal inflammation J Am Soc Nephrol 2010, 21:1254-1262

37. De Borst MH, Prakash J, Melenhorst WB, van den Heuvel MC, Kok RJ, Navis G, van Goor H: Glomerular and tubular induction of the transcription factor C-Jun in human renal disease. J Pathol 2007 , 213:219-228

38. de Graauw M, Tijdens I, Cramer R, Corless S, Timms JF, van de Water B: Heat shock protein 27 is the major differentially phosphorylated protein involved in renal epithelial cellular stress response and controls focal adhesion organization and apoptosis. J Biol Chem 2005 , 280:29885-29898

39. Takino T, Nakada M, Miyamori H, Watanabe Y, Sato T, Gantulga D, Yoshioka K, Yamada KM, Sato H: JSAP1/JIP3 cooperates with focal adhesion kinase to regulate c-Jun N-terminal kinase and cell migration. J Biol Chem 2005, 280:37772-37781

40. Shi Q, Hjelmeland AB, Keir ST, Song L, Wickman S, Jackson D, Ohmori O, Bigner DD, Friedman HS, Rich JN: A novel low-molecular weight inhibitor of focal adhesion kinase. TAE226, inhibits glioma growth. Mol Carcinog 2007, 46:488-496 